\title{
Responsabilidad Internacional de los Estados por violación al Pacto de San José: un breve reconocimiento de las obligaciones en el marco del Sistema Interamericano
}

\section{States International Responsibility for violation of Pact of San Jose: a brief study of obligations under the American System}

\section{RESUMEN}

Las obligaciones internacionales que en materia de derechos humanos han adquirido los Estados, se encuentran contenidas fundamentalmente en Tratados dictados por la comunidad internacional. Sus resultados son considerados estándares internacionales: en esencia, reglas de conducta a seguir por parte de los diferentes ordenamientos domésticos con la finalidad de cumplir los deberes asumidos, o en el mejor de los casos para respetar la dignidad humana.

A pesar de ello, en algunos sectores aún no resulta fácil reconocer y asimilar las bases de la responsabilidad internacional a la luz del SIDH, pues la clásica teoría del daño vigente en el ordenamiento jurídico de los Estados resulta ser un oponente muy obstinado. Por tanto el presente documento busca esencialmente su reconocimiento y asimilación.

En ese interregno, una serie de interrogantes sin respuestas se erigen hacia la jurisprudencia interamericana, en temas como las bases teóricas de la responsabilidad, el papel del estándar internacional en procesos de justicia transicional, la falta de reparación como causal autónoma de la responsabilidad internacional, o la recepción de la teoría del control de convencionalidad por parte del derecho constitucional interno; aspectos que se tocan tangencialmente en el presente documento.

\section{PALABRAS CLAVE}

Sistema Interamericano de Derechos Humanos, obligaciones internacionales en Derechos Humanos, Responsabilidad Internacional del Estado.

El presente artículo académico es realizado a partir de los resultados obtenidos en la investigación "Obligaciones internacionales en Derechos Humanos y políticas públicas. A propósito del caso colombiano", realizada por el autor y publicada por la Editorial de la Universidad Surcolombiana en diciembre de 2012. 


\section{ABSTRACT}

The States have obligations in international human rights which are mainly contained in treaties dictated by the international community. Their results are considered international standards. They are essentially rules of conduct to be followed by the different orderings household in order to fulfill the obligations undertaken, or the best to respect human dignity.

However, in some sectors the fundamentals of international responsibility against the rules of human rights system is not easy to recognize and assimilate, as the classical theory of harm in the legal force of the United happens to be a stubborn opponent. This paper therefore aims primarily at recognition and assimilation.

In this period, a number of questions without answers are directed toward the Interamerican jurisprudence on issues such as the theoretical basis of responsibility, the role of international standard transitional justice processes, the absence of repair as causal of the international responsibility, or the reception of the theory of control of compliance by the constitutional law; aspects that touch tangentially this papers.

\section{KEYWORDS}

Inter-American System of Human Rights, international Human Rights obligations, international State Responsibility.

\section{INTRODUCCIÓN}

Al referirse a los sistemas de protección de derechos humanos en general, se alude indefectiblemente a aquellos tribunales que por virtud de un tratado internacional, protegen derechos de la persona humana, mediante preceptos establecidos y desarrollados por la doctrina y jurisprudencia internacional. En tal ejercicio, vienen a la mente algunos Organismos de Naciones Unidas (como los Comités), u otros Regionales (como el Tribunal de Estrasburgo, la Comisión Africana, la Comisión o la Corte IDH), pero así mismo aquellos que imprimen relevante importancia a la labor proteccionista como sucede con la CIJ o Tribunales de tipo penal internacional como se aludirán líneas abajo.

En lo que tiene que ver con el Sistema Interamericano, la observancia inicia por el reconocimiento del mismo como un escenario importante de la jurisdicción internacional, pero de igual manera como un estadio de control político en relación con el cumplimiento de las obligaciones asumidas por los Estados (Faúndez Ledesma, 2004). Uno y otro se activan, 0 bien en virtud de alguna de las funciones desplegadas por sus principales organismos (como un informe emitido por la CIDH o una OC dictada por la Corte), o por determinados procedimientos (una petición individual, una visita in loco, una demanda); pero todo ello en razón de la condición del Estado al interior de la organización 0 en relación con determinado tratado (miembro o parte ${ }^{1}$ ).

Bajo tal contexto, la exigibilidad jurídica de los derechos se encuentra precedida por las normas y principios del derecho internacional, así como por las obligaciones supranacionales y la especial naturaleza de la responsabilidad internacional en los

1.-A la luz del Derecho de los Tratados, por Estados Parte se reconocen todos aquellos que han ratificado un Convenio, Pacto o Tratado, con independencia a si han aceptado la competencia de determinados Tribunales para la exigencia de las obligaciones contenidas en el respectivo instrumento, tal como sucede con la relacionada a la Corte IDH para el caso de la CADH. Tal acepción se diferencia de la expresión Estados Miembro, pues ésta designación hace referencia a los pertenecientes a una organización de tipo regional o universal, como es el caso de la OEA o la ONU, las cuales configuran de manera ejemplificante lo que se conoce como 'comunidad internacional'. Esta precisión resulta importante, pues las obligaciones dimanantes de dicha adherencia implican, teóricamente, responsabilidad política y jurídica, para cuyas respectivas exigencias resulta relevante la posición o situación de los Estados frente a la Organización y a los Tratados según la precisión reciente 
marcos del Derecho Internacional de los Derechos Humanos, lo que encuentra un particular eco en la interpretación proteccionista que ofrece el Sistema Regional Americano.

Por tanto, el presente documento busca explorar las bases de la responsabilidad internacional desde un examen estrictamente jurídico, a partir del reconocimiento de las obligaciones generales adquiridas por los Estados Parte de la Convención Americana sobre Derechos Humanos, con un enfoque especial en el caso colombiano. En dicho recorrido, se hace alusión tangencial a algunas zonas oscuras de la responsabilidad internacional a partir de las teorías del daño, al tiempo que finaliza con reflexiones puntuales sobre la eventual responsabilidad del Estado por la conculcación autónoma al deber de reparación.

A pesar de lo anterior, el presente documento previene un sentido pedagógico sobre los conceptos necesarios para la asimilación del Sistema Regional. De esta manera el presente texto logra su cometido, si al finalizar su revisión, el lector ha cosechado para su haber cognitivo, ideas básicas y generales sobre el derecho internacional de los derechos humanos y sistemas de protección, junto a un infinito de preguntas urgidas de obtener respuestas. Para ello, una premisa fundamental es tener un sentido de apertura frente al conocimiento y tomar con buen recibo la nueva información. La labor entonces no es aprehender, es desaprender para vislumbrar otro horizonte, el cual resulta significativamente distinto al derecho que en muchas oportunidades conocemos al interior de nuestro ordenamiento jurídico colombiano.

\section{OBLIGACIONES A LA LUZ DEL SISTEMA INTERAMERICANO DE PROTECCIÓN}

\begin{abstract}
Al realizar un análisis sobre las obligaciones que en materia de derechos humanos han asumido los Estados Parte de la Convención Americana sobre Derechos Humanos, será necesario convenir en que dicho estudio, ha de fundamentarse indefectiblemente en los precedentes (Becerra Ramírez, 1998) $)^{2}$ que los tribunales del SIDH ${ }^{3}$ han establecido y decantado como estándares internacionales ${ }^{4}$ para su cumplimiento, pero además, deberá descansar sobre desarrollos jurisprudenciales emanados por Cortes homólogas o de derecho internacional general ${ }^{5}$.
\end{abstract}

2.-Desde sus inicios, las decisiones de los Organismos del SIDH (Comisión y Corte Interamericana) se han fundamentado en el precedente judicial de tribunales externos sean o no homólogos, así como de sus propias decisiones. Ello conforme a la práctica de cortes internacionales, reconocida y aceptada en el derecho internacional desde la otrora Corte Permanente de Justicia Internacional o la actual Corte Internacional de Justicia, con reconocimiento expreso, además, en ciertos instrumentos como el artículo 31 de la Convención de Viena Sobre el Derecho de los Tratados de 1969 y el artículo 38 del Estatuto de la CIJ.

3.-Los principales órganos del SIDH son la Comisión y Corte Interamericana de Derechos Humanos. La Comisión cumple funciones de prevención, promoción y protección de estos derechos a través de diferentes acciones, entre otras el conocimiento de casos derivada de los artículos 41 a 51 de la CADH así como de los artículos 23 a 50 de su nuevo Reglamento (2010 y las modificaciones sufridas durante el proceso de fortalecimiento) lo cual la configura como organismo cuasijurisdiccional. Por su parte, la Corte recobra funciones inminentemente jurisdiccionales, por medio de dos funciones claramente establecidas: la Consultiva radicada en el artículo 64 convencional, y la contenciosa presente en el artículo 61 del Pacto. La diferencia entre la calidad de los tribunales (jurisdiccional-cuasijurisdiccional) deviene de lo vinculantes que resultan sus decisiones en el estudio de casos, como lo entiende el artículo 31.1 de la precitada Convención de Viena, pues mientras la Comisión emite "recomendaciones", la Corte dicta "sentencias" en sentido estricto, siendo que las primeras no son obligatorias a los Estados Parte y las segundas sí. Para una mejor referencia véase CrIDH, Caso Caballero Delgado, Sentencia de 8 de diciembre de 1995, Serie C No. 22, párr. 67.

4.-Por estándar internacional en el marco del SIDH se entienden los requisitos mínimos desarrollados por la doctrina y jurisprudencia internacional, necesarios para el cumplimiento de las obligaciones en derechos humanos.

5.-Son tribunales homólogos todos aquellos caracterizados por su naturaleza proteccionista en el campo de los derechos humanos, como es el caso de la Corte Europea de Derechos Humanos, la antigua Comisión Europea de Derechos Humanos, Comisión Africana de Derechos Humanos y de los Pueblos, Comité de Derechos Humanos, Comité de Derechos Económicos Sociales y Culturales entre otros. También constituyen una fuente importante de interpretación, los pronunciamientos de tribunales que sin contener una función en idéntico sentido, sus decisiones resultan relevantes a la luz del derecho internacional, como suele suceder con la CPJI, CIJ, CPI, TPIR y TPIY principalmente. 
Cuando se trate de un cas d'espèce, dicha elucidación atenderá de igual manera la ratificación de tratados universales y regionales sobre derechos humanos por parte del Estado involucrado, a fin de determinar su exigibilidad o vinculación desde una esfera hermenéutica al aplicar las normas de interpretación de la Convención de Viena Sobre el Derecho de los Tratados ${ }^{6}$, así como del principio pro homine (Pinto, $1997^{7}$ ), regla de derecho internacional encarnada en el artículo 29 de la CADH que previene el concepto de estándar más favorable, y por cuyo conducto se permite la vinculación de un amplio corpus iuris ${ }^{8}$, institución integrada por normas de diferente naturaleza, ya sean éstas exigibles a los Estados Parte en stricto sensu, o bien se trate de aquellas que aún pertenecientes al soft law (Uprimny, 2009) ${ }^{9}$, son fuente importante de interpretación.

\subsection{Estructura de las obligaciones derivadas de la Convención Americana}

El Pacto de San José de Costa Rica previene un catálogo de derechos y obligaciones contenido en los Capítulos I, II y III de la Parte I de dicho instrumento, acápites enmarcados como Enumeración de Deberes (Arts. 1 y 2), Derechos
Civiles y Políticos (Arts. 3 al 25) y Desarrollo Progresivo ${ }^{10}$ (Art. 26) respectivamente, así como lo relativo a las reparaciones delArtículo 63.1.

Las obligaciones generales de los artículos 1.1 y 2 irradian el objeto y fin de la Convención a lo largo de su cuerpo normativo, por lo tanto, la Corte IDH ha establecido que su entendimiento deriva la actitud en general que deben asumir los Estados para su cumplimiento, situación contraria que provocará el proceso internacional por la inobservancia de los deberes asumidos. En tal sentido, aquellas constituyen en definitiva la base para la determinación de responsabilidad internacional de un Estado por violaciones a la misma, de manera tal que dicho instrumento constituye lex specialis en materia de responsabilidad estatal, en razón de su especial naturaleza de tratado internacional de derechos humanos vis-à-vis el Derecho Internacional General $^{11}$, lo cual se apoya en las normas de interpretación y aplicación que para este campo prevé la misma Convención, según lo desarrollado por la jurisprudencia interamericana. ${ }^{12}$

Para identificar y reconocer la manera en que dichos compromisos deben ser cumplidos por las Altas Partes contratantes, será necesario retomar los

6.-Art. 31 Convención de Viena Sobre el Derecho de los Tratados de 1969.

7.-Según la autora, se trata de un criterio hermenéutico que informa todo el derecho internacional de los derechos humanos, en virtud del cual se debe acudir a la norma más amplia, o a la interpretación más extensiva, cuando se trata de reconocer derechos protegidos, e inversamente, a la norma o a la interpretación más restringida cuando se trata de establecer restricciones permanentes al ejercicio de los derechos o su suspensión extraordinaria. Este concepto ha sido reconocido igualmente por la Corte IDH en casos como Herrera Ulloa, Sentencia de 2 de julio de 2004, Serie C No. 107, párr. 184.

8.- $\mathrm{CrIDH}$, Condición Jurídica y Derechos de los Migrantes Indocumentados, Opinión Consultiva OC 18/03 del 17 de septiembre de 2003, Serie A No. 18, párr. 120. En este pronunciamiento la Corte manifestó que [e]l corpus juris del Derecho Internacional de los Derechos Humanos está formado por un conjunto de instrumentos internacionales de contenido y efectos jurídicos variados (tratados, convenios, resoluciones y declaraciones). Su evolución dinámica ha ejercido un impacto positivo en el Derecho Internacional, en el sentido de afirmar y desarrollar la aptitud de este último para regular las relaciones entre los Estados y los seres humanos bajo sus respectivas jurisdicciones.

9.-El soft law, o derecho suave, es un concepto propio del derecho internacional, con el cual se identifican fundamentalmente aquellos documentos que indican pautas para la protección o interpretación de derechos específicos u obligaciones generales. Emanan de órganos internacionales autorizados sin alcanzar el status de vinculante, y en consecuencia su contenido no se hace exigible en forma directa a los Estados.

10.-Aunque el desarrollo progresivo atiende diferentes aspectos o nociones, en el marco de la Convención el artículo 26 apunta fundamentalmente a aquellos derechos de carácter programático que tradicionalmente se encuentran relacionados con los DESC.

11.-Cfr. CrIDH, Caso de la Masacre de Mapiripán, Sentencia de 15 de septiembre de 2005, Serie C No. 134, párr. 107.

12.-El propio preámbulo de la Convención Americana en su párrafo 3 se refiere expresamente a los principios reafirmados y desarrollados en instrumentos internacionales, "tanto de ámbito universal como regional" y el artículo 29 obliga a interpretarla en atención a la Declaración Americana "y otros actos internacionales de la misma naturaleza". 
juicios jurídicos por medio de los cuales éstos son encontrados responsables en la esfera internacional, pues dicho de otra manera, se deberá entender la declaratoria de responsabilidad internacional por el incumplimiento de las obligaciones generales asumidas, para elucidar la disposición que debe tomar cada uno de los Estados Parte en aras de cumplir cabalmente el Convenio ratificado (Medina Quiroga, 2005). Así, mediante sólidos pronunciamientos, la Corte Interamericana ha manifestado que:

Desde sus primeros casos, la Corte ha basado su jurisprudencia en el carácter especial de la Convención Americana en el marco del Derecho Internacional de los Derechos Humanos. Dicha Convención, así como los demás tratados de derechos humanos, se inspiran en valores comunes superiores (centrados en la protección del ser humano), están dotados de mecanismos específicos de supervisión, se aplican de conformidad con la noción de garantía colectiva, consagran obligaciones de carácter esencialmente objetivo, y tienen una naturaleza especial, que los diferencian de los demás tratados, los cuales reglamentan intereses recíprocos entre los Estados Parte. ${ }^{13}$

\section{Esta especial naturaleza de dichos tratados y} su mecanismo de implementación colectiva, conllevan la necesidad de aplicar e interpretar sus disposiciones, de acuerdo con su objeto y fin, de modo a asegurar que los Estados Parte garanticen su cumplimiento y sus efectos propios (effet utile) en el plano de sus respectivos derechos internos. Este principio se aplica no sólo en relación con las normas sustantivas de los tratados de derechos humanos (es decir, las que contienen disposiciones sobre los derechos protegidos), sino también en relación con las normas procesales. ${ }^{14}$

Asimismo, la Corte ha señalado, al igual que la Corte Europea de Derechos Humanos, que los tratados de derechos humanos son instrumentos vivos, cuya interpretación tiene que acompañar la evolución de los tiempos y las condiciones de vida actuales. ${ }^{15}$

Bajo el horizonte hermenéutico indicado, la base de la responsabilidad internacional ante el SIDH se fundamenta en el quebranto a derechos humanos, estrecha e ineludiblemente relacionados con las obligaciones generales de los artículos 1.1 y 2 convencionales, mas no en la generación del daño como lo plantean algunas teorías de la responsabilidad (especialmente civil 0 del Estado en sede interna $)^{16}$, debido a que por diferentes razones, este último postulado resulta restrictivo ante la naturaleza de la Convención Americana

13.-CrIDH, Caso del Tribunal Constitucional, Sentencia de 24 de septiembre de 1999, Serie C No. 55, párr. 41; y, Caso Ivcher Bronstein, Sentencia de 24 de septiembre de 1999, Serie C No. 54, párr. 42.

14.- La Corte Interamericana retoma la doctrina jurídica de la Corte Europea sobre el efecto útil de los tratados, la cual establece que "[...] In the Court's view, the effectiveness (l'effet utile) of the Convention implies in such circumstances some possibility of having access to the Commission. If this were not so, the efficiency of the Convention's enforcement machinery would be materially weakened. The procedural provisions of the Convention must, in view of the fact that the Convention and its institutions were set up to protect the individual, be applied in a manner which serves to make the system of individual applications efficacious", Caso Klass y otros v. Alemania, Fallo de septiembre 6 de 1978, Serie A No. 28, párr. 34.

15.-CrIDH, El Derecho a la Información sobre la Asistencia Consular en el Marco de las Garantías del Debido Proceso Legal", Opinión Consultiva OC-16/99 de 1 de octubre de 1999, Serie A No. 16, párr. 114; Caso Juan Humberto Sánchez, Sentencia de 26 de noviembre de 2003, Serie CNo. 102, párr. 56.

16.-Lo primero que se debe reconocer en materia de responsabilidad estatal en los marcos del SIDH, es que tal efecto jurídico se fundamenta en principios del Derecho Internacional de los Derechos Humanos, con particular acento en los marcos del Derecho Internacional General. Por tal razón, pierden interés las teorías sobre la responsabilidad civil (contractual o extracontractual), así como las nociones del daño antijurídico o especial, el riesgo excepcional, o las fallas del servicio (propias de la jurisdicción administrativa), ya que la responsabilidad internacional de los Estados a la luz de la CADH se genera por la violación a un derecho humano lo que encarna el incumplimiento de las obligaciones generales; y no por la generación de un daño. Ante el Sistema Interamericano el daño no es analizado como un elemento determinante de la responsabilidad, sino como un efecto de la violación y en tal sentido un aspecto propio del campo de las reparaciones, por lo tanto, el centro de discusión para efectos de responsabilidad ante la Corte Interamericana es la conculcación al derecho. Es tal la naturaleza especial de la responsabilidad a la luz del sistema regional, que aún la teoría del ilícito internacional ampliamente abordada desde sus orígenes por la Comisión de Derecho Internacional de la ONU, especialmente desde 1967 cuando dio inicio al Proyecto Sobre Responsabilidad Internacional el cual finalizó en el año 2001, no es fielmente acogida por la Corte Interamericana, tal vez, porque entre otras razones, deviene de un fuerte sentido regulatorio de las obligaciones exigibles entre los Estados y no las de éstos respecto a los seres humanos sujetos a su jurisdicción. De hecho, las bases teóricas de la responsabilidad internacional en el DIDH, atienden a otros postulados como el papel de garante o la situación de riesgo, los cuales explican la violación a los Derechos Humanos a consecuencia, o bien del descuido estatal cuando tiene una obligación reforzada sobre determinadas personas o comunidades, o bien porque fue quien generó la situación de riesgo para la conculcación final. 
en los parámetros del DIDH ${ }^{17}$ (Feria Tinta, 2008), afirmaciones que devienen de reconocer el contenido, alcance y entendimiento de tales premisas como sucintamente se recogen a continuación.

A partir de exámenes acuciosos al artículo 1.1, se ha entendido que los deberes generales de los Estados Parte se componen de dos grandes obligaciones: 1) la de respetar los derechos y libertades y, 2) la de garantizar su libre y pleno ejercicio; compromisos que en su conjunto deben ser atendidos sin discriminación alguna. ${ }^{18}$

\subsection{Obligación de respeto}

Desde sus inicios, la Corte ha manifestado que el primer deber asumido por las Altas Partes Contratantes, en los términos del citado artículo, es el de respetar los derechos y libertades reconocidos en la Convención, por cuanto el ejercicio de la función pública tiene unos límites que derivan de que los derechos humanos son atributos inherentes a la dignidad humana y, en consecuencia, superiores al poder del Estado, ${ }^{19}$ por lo tanto dicha obligación es negativa y en principio, se erige como objetiva o de resultado. $^{20} \mathrm{Ya}$ en un precedente anterior bajo la función consultiva, el tribunal había indicado que la protección a los derechos humanos, parte de la afirmación de la existencia de ciertos atributos inviolables de la persona humana que no pueden ser legítimamente menoscabados por el ejercicio del poder público, pues se trata de esferas individuales que el Estado no puede vulnerar o en los que sólo puede penetrar limitadamente y de esta manera está necesariamente comprendida la noción de la restricción al ejercicio del poder estatal. ${ }^{21}$

Así fue como en sus albores jurisprudenciales, la Corte consideró que la obligación negativa recae esencialmente (no en forma exclusiva) sobre los derechos reconocidos como civiles y políticos, y entre éstos, particularmente respecto de aquellos ante los cuales el Estado se ve obligado a guardar absoluta distancia; es decir, los que de entrada para su goce no requieren ningún tipo de intervención del poder estatal, vr. gr. el derecho a la vida, a la libertad personal, o a la integridad personal cuando este último se relaciona con el derecho a no ser torturado; pues de actuar en contravía a tal mandato, podría atribuírsele responsabilidad internacional al Estado por infracciones de tal naturaleza, aun cuando dichos menoscabos fueran generados por la acción u omisión de cualquier autoridad pública o terceros particulares, según los principios generales del derecho internacional. ${ }^{22}$ Adicionalmente, existen situaciones en las cuales el poder estatal contraviene la obligación negativa por actos que en principio le resultan legítimos al Estado, como suele suceder con la expedición o aplicación de normas contrarias a la Convención.

17.-Para una mejor referencia sobre responsabilidad internacional de los Estados Parte por violación a la Convención Americana, véase desde una óptica de la responsabilidad, CrIDH, Caso Velásquez Rodríguez, Sentencia de 26 de junio de 1987, Serie C No. 1 y Sentencia de 29 de julio de 1988, Serie C No. 4; Caso de las niñas Yean y Bosico, Sentencia de 8 de septiembre de 2005, Serie C No. 130; Caso Gutiérrez Soler, Sentencia de 12 de septiembre de 2005, Serie C No. 132; Caso del Penal Miguel Castro Castro, Sentencia de 25 de noviembre de 2006, Serie C No. 160; Caso de la Masacre de Mapiripán, ob. cit.; Caso de las Masacres de Ituango, Sentencia de 1 de julio de 2006, Serie C No. 148; Caso de la Masacre de Pueblo Bello, Sentencia de 31 de enero de 2006, Serie C No. 140; Caso de la Masacre de la Rochela, Sentencia de 11 de de mayo de 2007, Serie C No. 163; Caso Xakmok Kasek vs Paraguay; Opinión Consultiva OC18/03, ob. cit.; así como los Votos Razonados del Juez Augusto Antonio Cançado Trindade en las sentencias de Fondo de los Casos Mapiripán, Pueblo Bello, Ituango, Rochela, Penal Miguel Castro Castro y de la Opinión Consultiva No. 18 ya citados.

18.-Cfr. CrIDH, Caso Velásquez Rodríguez, ob. cit. párrs. 164 a 167.

19.-Cfr. CrIDH, Caso Godínez Cruz, Sentencia de 20 de enero de 1989. Serie C No. 5, párr. 174.

20.-Cfr. CrIDH, Voto Razonado del Juez Cançado Trindade en Opinión Consultiva OC-18/03, párr. 71; Caso Baena Ricardo, Sentencia de 28 de noviembre de 2003, Serie C No. 104, párr. 96.

21.- Cfr. CrIDH, La expresión "leyes" en el artículo 30 de la Convención Americana Sobre Derechos Humanos, OC-6/86 del 9 de mayo de 1986. Serie A No. 6, párr. 21.

22.-Cfr. CrIDH, Caso Fairén Garbi, Sentencia de 15 de marzo de 1989, Serie C No. 6, párr. 152. 
Con el paso del tiempo y en la medida en que la jurisprudencia interamericana evolucionó, especialmente a partir de casos relacionados con graves y sistemáticas violaciones a derechos humanos ${ }^{23}$ ocurridas en contextos de permanente alteración del orden público, dictaduras, 0 de conflictos armados internos, la Corte amplió los estándares de protección al hacer uso y desarrollo, con mayor claridad, de los diversos principios de derecho internacional a que aludía en sus inicios; así como de vincular en algunas oportunidades conceptos arraigados en otras materias del derecho internacional, como por ejemplo del derecho internacional humanitario. ${ }^{24}$ Los preceptos fundamentales de dicho progreso se encuentran fundamentalmente, en diferentes sentencias relacionadas con asuntos peruanos, hondureños 0 guatemaltecos, pero con particular acierto en los casos de las masacres de Ituango, Pueblo Bello, la Rochela o 19 Comerciantes contra Colombia; siendo la sentencia de fondo en el caso de la masacre de Mapiripán, la que asienta con mayor vigor la línea interpretativa respecto de las violaciones atribuibles al Estado, especialmente cuando la afectación recae sobre la obligación de respeto.
Al afianzar su complexión evolutiva, retomó precedentes del Tribunal de Estrasburgo para desarrollar interpretaciones mediante las cuales concibió que la obligación negativa a cargo de los Estados se menoscaba, siempre que estos generen actos $u$ omisiones emanados por cualquier poder $u$ órgano estatal, independientemente de su jerarquía, produciendo en forma inmediata el ilícito internacional atribuible al Estado ${ }^{25}$, sin que para ello se requiera determinar la culpabilidad de los autores, su intencionalidad o la identificación de los agentes causantes de la conculcación como sucede en derecho interno. Tal efecto jurídico cobra similar vigor ante el incumplimiento del Estado por la acción u omisión de sus agentes cuando aquél se encuentra en la posición de garante ${ }^{26}$, pues para ello resulta suficiente la demostración de que ha habido apoyo 0 tolerancia del poder público en la infracción de los derechos reconocidos en la Convención ${ }^{27}$, así como omisiones que hayan permitido la perpetración de violaciones.

Consideró además que la responsabilidad internacional también podría ser atribuida por actos de particulares en principio no imputable

23.-El término violaciones sistemáticas ha sido implementado por la Corte Interamericana desde sus primeros casos para identificar aquellas prácticas violatorias de derechos humanos ocurridas de manera recurrente al interior de un Estado durante lapsos específicos, y que siendo ejecutadas por el poder estatal o terceros particulares, la actitud del Estado ha sido pasiva y tolerante. Para una mejor referencia, véase Cfr. CrIDH, Caso Velásquez Rodríguez, ob. cit. párrs. 147 y 188; Caso de la Masacre de Pueblo Bello, ob. cit. párr. 128. Por su parte, por violaciones graves, la jurisprudencia de la Corte reconoce aquellas que atentan contra derechos inderogables de la persona humana de acuerdo al Derecho Internacional de los Derechos Humanos, infracciones regularmente relacionadas con la tortura, las ejecuciones sumarias, extralegales o arbitrarias y las desapariciones forzadas; para una mejor referencia ver Cfr. CrIDH, Caso Barrios Altos, Sentencia de 14 de marzo de 2001, Serie C No. 75, párr. 41.

24.-Si bien existe una clara diferenciación entre la naturaleza, finalidad y ámbito de aplicación del DIH y DIDH, cuando las violaciones a los derechos humanos han ocurrido en contextos de conflictos armados, la Corte ha entendido que es posible hacer uso de normas pertenecientes al DIH para la determinación de responsabilidad del Estado. Cfr. CrIDH, Casos Bámaca Velásquez, Sentencia de 25 de noviembre de 2000, Serie C No. 70, párrs. 208 a 209; Las Palmeras vs Colombia (Fondo), Sentencia de 6 de diciembre de 2001, Serie C No. 90. Tópicos similares han sido recientemente abordados por la jurisprudencia de la Corte en los Casos Manuel Cepeda Vargas y Masacre de Santo Domingo vs Colombia, así como en las Masacres de el Mozote y lugares aledaños vs El Salvador, pronunciamientos en los que además se ha discutido el valor del DPI para la determinación de responsabilidad internacional y la autonomía de los Estados en procesos de Justicia Transicional. Doctrinariamente, las aparentes exclusiones entre las diferentes ramas del derecho se resuelve en favor de la persona, no solo a partir del concepto de cuerpo jurídico y principio pro homine, sino al reconocer que la vigencia de los DDHH no se ausenta en tiempos de conflicto, pues al contrario el DIH presenta una protección reforzada al núcleo básico de derechos humanos en tiempos de conflicto (vida, integridad, libertad y acceso a la justicia), el cual es inderogable bajo cualquier circunstancia; a su turno, el DPI busca la materialización del deber de investigación estatal, cuyos crímenes pueden ser cometidos en tiempos de paz o de conflicto armado, con excepción a los delitos de guerra y al de agresión (según la tipología del Estatuto de Roma). Por tanto, dichos ámbitos prestan un valioso aporte para la identificación y explicación de los contextos, como un elemento necesario en el estudio de casos.

25.-Cfr. CrIDH, Caso de la Masacre de Mapiripán, ob. cit. párr. 110.

26.-Cfr. CrIDH, Caso de la Masacre de Pueblo Bello, ob. cit. párr. 113.

27.- Cfr. CrIDH, Caso 19 Comerciantes, Sentencia de 5 de julio de 2004. Serie C No. 109, párr. 141; Caso Cantos, Sentencia de 28 de Noviembre de 2002, Serie C No. 97, párr. 28. 
a los Estados parte, debido a que éstos tienen obligaciones erga omnes (Cebada Romero, 2002) de respetar y hacer respetar las normas de protección, y de asegurar la efectividad de los derechos consagrados convencionalmente en toda circunstancia y respecto de toda persona. ${ }^{28}$ Dichas obligaciones proyectan sus efectos más allá de la relación entre sus agentes y las personas sometidas a su jurisdicción, pues ellas se manifiestan en la obligación positiva a cargo de los Estados de adoptar todas las medidas necesarias para asegurar la efectiva protección de los derechos humanos en las relaciones inter-individuales, conforme al sentido desarrollado por la doctrina jurídica y particularmente por la teoría del Drittwirkung (Mijangos y González, 2007), teoría según la cual los derechos fundamentales deben ser respetados tanto por los poderes públicos como por los particulares en relación con otros particulares. ${ }^{29}$

La obligatoriedad irrestricta en el cumplimiento del deber de respeto, en esta etapa de la Corte, se fundamenta en un escenario de precedentes provistos por la escena universal, el cual provee valiosos insumos para el estudio interpretativo sobre la materia. En tal sentido, acude (entre otros) a la Corte Internacional de Justicia en variados precedentes como el Relacionado con las acciones militares y paramilitares en y contra Nicaragua
(Nicaragua vs Estados Unidos) $)^{30}$, 0 en la Opinión Consultiva sobre la Legalidad en la amenaza o empleo de armas nucleares ${ }^{31}$, para enfatizar el contenido y alcance de las obligaciones contraídas por los Estados en el derecho supranacional, tal como lo han reconocido otros organismos internacionales ${ }^{32}$ demostrando la consolidación de opinio juris communis sobre el particular.

Tras aludir dichos compromisos, realiza un análisis a través del cual advierte la importancia de las obligaciones generales de carácter erga omnes existentes en el ámbito internacional, las cuales confinan características específicas de superioridad respecto de otras que comparten el mismo escenario, pues aquellas (presentes en tratados de derechos humanos) se identifican en muchos casos con el derecho de gentes (ius cogens), concepto que fue consagrado positivamente en el artículo 53 común a las Convenciones de Viena Sobre Derecho de los Tratados de 1969 y 1986, y cuyo tratamiento se abordó con respetado acierto por la ClJ en su célebre caso Barcelona Traction de $1970^{33}$; apreciaciones éstas que se encuentran ampliamente expuestas en algunos votos del Juez Cançado Trindade. ${ }^{34}$

De esta manera se puede concluir que el Estado puede restringir el cumplimiento de la obligación negativa de dos maneras: 1) mediante la

28.-Cfr. CrIDH, Opinión Consultiva OC-18/03, ob. cit. párr. 140.

29.-CrIDH, Caso Bulacio, Sentencia de 18 de septiembre de 2003, Serie C No. 100, párr. 111; Caso de las Penitenciarias de Mendoza, Medidas Provisionales, Resolución de 18 de junio de 2005; Caso de la Comunidad Kankuamo, Medidas Provisiones, Resolución de 5 de julio de 2004; Caso de las Comunidades del Jiguamiandó y del Curbaradó, Medidas Provisionales, Resolución de 6 de marzo de 2003, Serie E No. 4; Caso de la Comunidad de Paz de San José Apartadó, Medidas Provisionales, Resolución de 18 de junio de 2002 , Serie E No. 4.

30.-Cfr. CIJ, Caso Relacionado con las Acciones Militares y Paramilitares en y contra Nicaragua (Nicaragua vs Estados Unidos), Fondo, Fallo del 27 de junio de 1986.

31.-Cfr. CIJ, Legalidad de la Amenaza o Uso de las Armas Nucleares, Opinión Consultiva del 8 de Julio de 1996.

32.- Cfr. TEDH, Caso de Irlanda v. Reino Unido, Fallo del 18 de junio de 1978, párr. 239; Caso Willis v. Reino Unido, Fallo del 11 de Junio de 2002, párr. 39; Caso Petrovic v. Austria, Fallo del 27 de Marzo de 1998, párr. 30; Caso "Relativo a ciertos aspectos de la ley en el uso del lenguaje en la educación belga" v. Bélgica, Fallo del 23 de Julio de 1968, párr. 10. Cfr. Comisión Africana de Derechos Humanos y de los Pueblos, Comunicación No. 211/98, Legal Resources Foundation v. Zambia, Decisión tomada en la 29 Sesión Ordinaria realizada en Tripoli, Libia, del 23 de abril al 07 de mayo de 2001, párr. 63. Cfr. T.P.I.Y, Juicio Chambre II: Fiscal v. Anto Furundzija, Fallo del 10 de diciembre de 1998, Caso No. IT-95-17/1-T, párrs. 137-146, 153-157. Cfr. CIJ, Aplicación de la Convención sobre la Prevención y Castigo a los Crímenes de Genocidio (Croacia v. Serbia), Fallo de Excepciones Preliminares, Informe de 1996, pág. 595; Las Reservas a la Convención sobre el Genocidio, Opinión Consultiva, Informe de 1951, pág. 15.

33.-Cfr. ClJ, Caso Relativo a la Barcelona Traction, Light and Power Company, Limited, (Bélgica v. España), Segunda Fase, Fallo del 05 de febrero de 1970.

34.-Cfr. CrIDH, Votos Razonados del Juez Cançado Trindade en ob. cit. Masacre de Mapiripán, Masacre de Pueblo Bello, Masacres de Ituango, Masacre de La Rochela, el Penal Miguel Castro Castro y Opinión Consultiva OC-18/03. 
manifestación de su autoridad a través de actos propios, y, 2) eventualmente tras la comisión de infracciones por particulares. Así, para el primero de los supuestos se entenderán comprometedoras las actuaciones o imprevisiones de cualquier órgano del poder público que resulten contrarias a la Convención, al igual que toda acción, omisión, o extralimitación en las funciones de los agentes del Estado aun cuando actúen en nombre propio. Por su parte, las transgresiones de particulares le son atribuibles a) cuando comporta el papel de garante; b) cuando los particulares han actuado con aquiescencia, connivencia o apoyo del aparato estatal o sus agentes, o finalmente c) cuando el Estado no ha atendido de manera eficaz la perpetración.

Cualquiera que sea la circunstancia de violación en casos específicos, al verificarse alguna de las anteriores condiciones el Estado se encuentra llamado a demostrar cuáles han sido las acciones que dentro de su estructura estatal se encuentran diseñadas para promover la protección de los derechos humanos, prevenir sus violaciones, atenderlas frente eventuales conculcaciones (investigar, enjuiciar y sancionar a los responsables cuando a ello haya lugar) así como generar las respectivas medidas de reparación integral de acuerdo a estándares internacionales, como actos propios de la obligaciones positiva.

\subsubsection{Obligación de garantía}

Sobre la obligación de garantía la Corte ha establecido que la misma puede ser cumplida de diferentes maneras, bien sea en función del derecho específico que el Estado deba garantizar, o bien de las particulares necesidades de protección. ${ }^{35}$ Por ello la segunda obligación general contemplada en el artículo 1.1 Convencional, conocida como de garantía o positiva, resulta ser, en cierta medida, un poco más amplia y compleja por la diversidad de medidas que en forma colectiva y a cargo de los Estados previene, así como por la manera en que debe ser implementada al interior de los ordenamientos; siendo ella una de las razones por las cuales, en principio, dicha obligación sea considerada como de conducta, medio 0 comportamiento.

Contrario sensu a la de respeto, para que la obligación positiva se materialice, el Estado debe ser proactivo en la implementación de un abanico amplio de acciones garantistas en diferentes escenarios. En los marcos del SIDH, esta situación no se corresponde de manera exclusiva con las medidas relativas a la cláusula de progresividad del artículo 26 Convencional, sino que además exige igual tratamiento para el caso de aquellos derechos que por su naturaleza requieren una adecuada organización del poder público para un goce real y efectivo, tal como sucede particularmente con los derechos concernientes a la igualdad o la justicia, concebidos en el cuerpo normativo del Pacto como garantías judiciales, protección judicial e igualdad ante la ley (artículos 8, 25 y 24 respectivamente), los cuales, en general, son el elemento fundamental en el cumplimiento del deber de atención en cuanto a investigación se refiere.

Más aún, existe un mayor nivel de exigencia en la implementación de mecanismos de garantía, en momentos en que el Estado considera necesario suspender o limitar el ejercicio de algunos derechos ${ }^{37}$, pues bajo tales condiciones los atributos recién indicados no podrán ser extraídos

35.-Cfr. CrIDH, Caso Perozo, Sentencia de 28 de enero de 2009, Serie C No. 195, párr. 298; Caso Anzualdo Castro, Sentencia de 22 de Septiembre de 2009, Serie C No. 202, párr. 62.

36.-Cfr. CrIDH, Caso Zambrano Vélez y otros, Sentencia de 4 de julio de 2007, Serie C No. 166, párr. 80; Caso Vargas Areco, Sentencia de 26 de septiembre de 2006, Serie CNo. 155, párr. 75.

37.- Cfr. CrIDH, Opinión Consultiva OC-6/86, ob. cit.; Hábeas Corpus Bajo Suspensión de Garantías (arts. 27.2, 25.1 y 7.6 Convención Americana sobre Derechos Humanos), Opinión Consultiva OC-8/87 del 30 de enero de 1987, Serie A No. 8; y, Garantías Judiciales en Estados de Emergencia (arts. 27.2, 25 y 8 Convención Americana sobre Derechos Humanos), Opinión Consultiva OC-9/87 del 6 de octubre de 1987, Serie A No. 9. 
temporalmente del ordenamiento interno, y en la mayoría de los casos no serán objeto de restricción; lo que en su conjunto apunta a evitar que el poder político surque los senderos de la desigualdad, la discriminación o la adopción de medidas ilegales o $\operatorname{arbitrarias}^{38}$ (O'Donell, 2004).

En efecto, esta obligación implica el deber de los Estados de organizar todo el aparato gubernamental $y$, en general, todas las estructuras a través de las cuales se manifiesta el ejercicio del poder público, de manera tal que sean capaces de asegurar jurídicamente el libre y pleno ejercicio de los derechos humanos ${ }^{39}$. Como parte de dicha obligación, el Estado se encuentra en el deber jurídico de prevenir, razonablemente, las violaciones de los derechos humanos, de investigar seriamente con los medios a su alcance las violaciones que se hayan cometido dentro del ámbito de su jurisdicción a fin de identificar a los responsables, de imponerles las sanciones pertinentes y de asegurar a la víctima una adecuada reparación ${ }^{40}$, pues lo decisivo es determinar si una violación ha tenido lugar con el apoyo o la tolerancia del poder público o si éste ha actuado de manera que la trasgresión se haya cumplido en defecto de toda prevención o impunemente.

Por ello, al tratar la generalidad del deber de conducta es menester reconocer que el mismo implica la disposición del aparato estatal tendiente a: 1) prevenir violaciones a los derechos humanos, así como 2) atender cuando eventualmente éstas han ocurrido.

\subsubsection{Obligaciones de prevención}

En lo referente a las obligaciones de prevención, interesa indicar que si bien éstas son las llamadas por excelencia a generar estadios culturales y sociales de promoción, respeto y reconocimiento de los derechos humanos al interior de los Estados, en la práctica no son enumerables y por consiguiente, en principio, no sancionables en forma directa (similar efecto al límite de justiciabilidad comportado actualmente por las del desarrollo progresivo), a diferencia de las destinadas a la atención como se verá infra.

Un razonamiento en idéntico orden se puede notar en la jurisprudencia de la Corte Interamericana, cuando manifiesta que

[ ‥] el deber de prevención abarca todas aquellas medidas de carácter jurídico, político, administrativo y cultural que promuevan la salvaguarda de los derechos humanos [...] [y por lo tanto] [n]o es posible hacer una enumeración detallada de esas medidas, que varían según el derecho de que se trate y según las condiciones propias de cada Estado Parte.

En cuanto a este tipo de obligaciones, hay que resaltar que será necesario diferenciar aquellas acciones instituidas al interior de un Estado para proteger 0 abordar en forma general, determinado derecho, comunidad o situación, como política estatal, de las que son, o deben ser tomadas ante el inminente riesgo de violaciones particulares $y$

38.-Si bien los conceptos desigual, discriminatorio, ilegal y arbitrario guardan cierta relación, también previenen algunas diferencias entre sí. La igualdad se entiende básicamente como la distinción de trato formal o material, la cual, puede o no, constituir discriminación, pues toda distinción tendiente a proteger derechos vulnerables de ciertas comunidades no podrá entenderse discriminatorio. Por su parte, la discriminación se refiere a toda exclusión, restricción o privilegio que no cumpla con los requisitos de objetividad, razonabilidad y proporcionalidad de forma que resulta contraria a la naturaleza de la justicia. Entre tanto el término ilegal se refiere a la falta de disposición legal o ante su existencia, a la adopción de medidas sin ajustarse a dicha normativa o al debido proceso; mientras que arbitrario es una acepción más cercana a la privación de la libertad, cuando ella no obedece a criterios razonables para la detención. Esta terminología ha sido desarrollada jurisprudencialmente por la CIDH y la CrIDH, así como por otros tribunales de protección de acuerdo a los análisis de proporcionalidad que proveen principalmente los artículos convencionales 27, 30 y 32 indicados anteriormente.

39.-Cfr. CrIDH, Caso Kawas Fernández, Sentencia de 3 de abril de 2009 Serie C No. 196, párr. 137.

40.-CrIDH, Caso Anzualdo Castro, ob. cit. párr. 62.

41.- Cfr. CrIDH, Caso Velásquez Rodríguez, ob. cit. párrs. 174 y 175. 
previsibles, pues en tal caso se hablaría de maniobras correspondientes con la posición de garante que comporta el Estado, en los términos ya señalados cuando se abordó la obligación de respeto líneas atrás, siendo un ejemplo de ello las violaciones cometidas en centros carcelarios 0 de detención, o grupos socialmente vulnerables.

\subsubsection{Obligaciones de atención}

Las obligaciones de atención (en igual plano que las de prevención) se relacionan con todas aquellas medidas de diferente índole, destinadas a atender una violación o a corregir sus causas mediante el diseño, ejecución e implementación de diferentes acciones coordinadas de su política pública ${ }^{42}$, siempre que guarden un diálogo acorde con las obligaciones convencionales aún bajo el amplio margen de apreciación con que el Estado cuenta para ello (García San José, 2001), y que de manera concreta se identifican con investigar, identificar, enjuiciar y sancionar a los responsables de las agresiones ${ }^{43}$; por lo que a diferencia de aquellas preventivas, éstas han sido claramente definidas por el sistema interamericano y en consecuencia, su incumplimiento genera efectos justiciables o exigibles. Ha dicho la $\mathrm{CrIDH}$ que como consecuencia de la segunda obligación asumida por los Estados Parte de la Convención, se debe prevenir, investigar y sancionar toda violación de los derechos reconocidos por la Convención y procurar, además, el restablecimiento, si es posible, del derecho conculcado y, en su caso, la reparación de los daños producidos por la violación de los derechos humanos. ${ }^{44}$

\subsubsection{Obligación de investigar y sancionar}

De acuerdo a las reglas del derecho internacional, la obligación de investigar, sancionar y reparar los daños ocurridos, se produce en el momento mismo en que se transgrede un deber de protección, pues claro parece, que en ausencia de afectaciones (violación a un derecho humano), no habría situaciones que investigar y en consecuencia, no sería necesario restablecer o reparar las secuelas de menoscabo alguno.

Al tratar la obligación de investigar separadamente del deber de reparar, resulta necesario advertir que bajo la doctrina universal y particularmente desde el enfoque dado por la jurisprudencia interamericana, aquella se fundamenta en el derecho a un recurso efectivo y el debido proceso, los cuales son los elementos necesarios para atender con debida eficacia el deber investigativo a cuenta del Estado, situación que además, es considerada como un derecho subjetivo de la víctima según exégesis de la doctrina regional ${ }^{45}$, aún en ausencia de toda acción legal iniciada por los particulares interesados.

Los derechos al recurso efectivo y a las garantías judiciales son tratados con relativa cercanía en la jurisprudencia del sistema regional, ya que tanto el primero como el segundo previenen la importancia de la existencia de un mecanismo jurisdiccional, siendo que la diferencia se encuentra marcada por el acento que a tal dispositivo le imprime el derecho a la protección judicial $^{46}$ (Rodríguez Rescia, 1998).

42.-Cfr. CrIDH, Opinión Consultiva OC 18/03, ob. cit. párr. 172

43.-Cfr. CrIDH, Caso González y otras (Campo Algodonero), Sentencia de 16 de noviembre de 2009, Serie C No. 205 párr. 236.

44.-Cfr. CrIDH, Caso Velásquez Rodríguez, ob. cit. párr. 166.

45.- A diferencia de la jurisprudencia universal o de la Corte Europea que considera separadamente los derechos a un recurso judicial y al debido proceso, la jurisprudencia de los órganos componentes del sistema interamericano tiende a calificar las violaciones del derecho a un recurso como violaciones de los artículos 8.1 y 25 en conjunto. En consecuencia, aunque la doctrina universal considera la investigación y la persecución penal de graves violaciones a los derechos humanos una obligación del Estado y no así un derecho de la víctima, la doctrina interamericana estima que la investigación y el castigo comportan un doble sentido: obligación exigible al Estado y un derecho subjetivo de la víctima y sus allegados. Cfr. CrIDH, Caso Blake, Sentencia de 24 de enero de 1998, Serie C No. 36, párrs. 96 a 97.

46.-Cuando el derecho a las garantías judiciales del artículo 8 convencional establece que [...] toda persona tiene derecho a ser oída [...], implícitamente marca un estándar mínimo de protección el cual parte indudablemente de la existencia de un recurso disponible al interesado para acudir a la justicia. Por su parte, el derecho a la protección judicial de que trata el artículo 25 del Pacto, imprime una característica particular a tal recurso cuando indica que el mismo deberá ser sencillo y rápido [...] que la ampare contra actos que violen sus derechos fundamentales reconocidos por la constitución, la ley o la presente Convención. Dicha particularidad ha permitido que la Corte entienda que el artículo 25 protege esta clase de recurso y no cualquier otro, a pesar que en determinados momentos sea necesario protegerlos conjuntamente. 
Si bien estos derechos complementarios son determinantes para la investigación y la sanción, no deben ser considerados únicamente como mecanismos destinados a la atención, pues como se verá a continuación, ellos cumplen funciones mucho más amplias en el extenso catálogo de estándares fijados para la protección de los derechos previstos en la Convención, ya que entre otras razones y al fin de cuentas, de acuerdo a la estructura convencional éstos hacen parte de los llamados derechos civiles y políticos y no corresponden orgánicamente a las obligaciones generales.

\subsubsection{La naturaleza del derecho a un recurso efectivo y al debido proceso}

En este punto debe hacerse una reflexión de carácter hermenéutico en cuanto a la naturaleza del derecho a un recurso efectivo que permita acceder a la justicia 0 iniciar cualquier tipo de procedimiento, sea éste judicial o administrativo, sancionatorio 0 de otra índole; así como al debido proceso.

Si bien, en teoría, el deber de investigar se encuentra en consonancia con aquellas obligaciones que en derecho internacional se reconocen como secundarias $^{47}$ (Perez Giralda, 2002), que se hacen exigibles al momento justo en que se transgreden las primarias $^{48}$ (Dworkin \& Hart, 1997) las cuales dan lugar a discusiones sobre el principio-regla (Zagrebelsky, 2005), es necesario determinar si la implementación de recursos efectivos en el ordenamiento interno y la aplicación del debido proceso en los diferente escenarios procesales, se corresponde con una acción propia de atención, o si además de ello, tales elementos se erigen como mecanismos de prevención, pues no resulta aceptable considerar que éstos (recurso y debido proceso) se activan únicamente ante la configuración de una violación al derecho humano como se tratará infra, y por tal condición, desconocer que dichos mecanismos hacen parte importante de las normas primarias, dependiendo entonces de la esfera de acción a la que se adecúen en determinados momentos 0 al enfoque con que respondan ante casos particulares.

Bajo tal razonamiento y para efectos prácticos, resulta valorable no perder de vista que este tipo de derechos se identifican con aquellos propios de la justicia, el debido proceso, así como la igualdad y no discriminación bajo ciertas circunstancias en los términos ya referidos con alguna anterioridad. De igual manera, parece útil reconocer que el análisis contencioso realizado a propósito de la violación a un derecho sustancial previsto por la Convención Americana, pero distinto a los aquí mencionados, generalmente se encuentra relacionado con la inobservancia a éstos (garantías judiciales y protección judicial), pues en un sinnúmero de casos la violación al debido proceso va de la mano, o es el corolario, de una inadecuada atención, por ejemplo, del menoscabo al derecho a la vida, a la libertad o a la integridad personal. ${ }^{49}$

Pero es igualmente cierto, que tales derechos son autónomos e independientes, y por tal razón, pueden ser desatendidos en forma primigenia, caso en el cual su inobservancia puede generar la violación a otros derechos relacionados con la libertad, la propiedad, la nacionalidad u otros, como se puede observar en los casos Kimel vs Argentina ${ }^{50}$, Salvador Chiriboga vs Ecuador ${ }^{51}$ o Ivcher Bronstein vs Perú ${ }^{52}$ por mencionar algunos. Así mismo los mecanismos

47.-Según la doctrina jurídica, por normas secundarias se entienden aquellas que se hacen exigibles al momento justo en que se trasgreden las primarias como un efecto inmediato, por lo que generalmente se encuentran relacionadas con las destinadas a investigar o reparar.

48.-A su turno, las reglas primarias imponen deberes positivos (acciones) o negativos (omisiones), que de acuerdo a la Convención Americana, serían las de respeto y garantía de los derechos humanos.

49.-Son innumerables los casos en que se presenta este fenómeno. Para una referencia ampliada, Cfr. CrIDH, Caso Valle Jaramillo y otros, Sentencia de 27 de noviembre de 2008, Serie C No. 192; Caso la Cantuta, Sentencia de 29 de noviembre de 2006, Serie C No. 162.

50.- Cfr. CrIDH, Caso Kimel, Sentencia de 2 de mayo de 2008, Serie C No. 177.

51.-Cfr. CrIDH, Caso Salvador Chiriboga, Sentencia de 6 de mayo de 2008, Serie C No. 179.

52.-Cfr. CrIDH, Caso Ivcher Bronstein, Sentencia de 6 de febrero de 2001, Serie C No. 74. 
que materializan estos derechos, en determinadas ocasiones requieren estar al alcance del individuo que pretende evitar afectaciones futuras, luego de la expedición de una norma discriminatoria, pues bajo tales supuestos, es necesario que ante la promulgación de una ley de no aplicación inmediata $^{53}$, el Estado posea los dispositivos necesarios para que el interesado acuda a la judicatura en debida reclamación.

De lo anterior se deduce que los derechos al recurso efectivo y a la protección judicial contenidos en los artículos 8 y 25 de la Convención, comportan características de prevención y atención en los marcos ya indicados, y en consecuencia, previenen una condición sui generis bien sea de manera separada o mixta en ciertas oportunidades. Por lo tanto se trata de derechos de especial importancia pues las garantías judiciales junto a la protección judicial, tutelan todos los demás derechos de la persona (O'Donell, 2004) con independencia a la esfera de acción a la que se circunscriban en determinados momentos.

La importancia del anterior análisis, incide en reconocer la exigencia a la que se aboca el Estado en la implementación de recursos efectivos al alcance de las personas sujetas a su jurisdicción, así como de garantizar el debido proceso en la sustanciación de todo tipo de procedimiento, pues ello corresponderá de igual manera al cumplimiento de obligaciones de primer y segundo nivel y por lo tanto representa un valor incalculable en los ordenamientos internos, dado que la existencia de esta garantía constituye uno de los pilares básicos no sólo del Pacto, sino del propio Estado de Derecho en una sociedad democrática contemporánea ${ }^{54}$, visto entonces como un deber general claramente establecido.

\subsubsection{Investigar, identificar, enjuiciary sancionar}

Ante ese contexto y al entrar en el análisis de la obligación propiamente dicha, la Corte entiende que los Estados Parte están obligados a suministrar recursos judiciales efectivos a las víctimas de violaciones de los derechos humanos, los cuales deben ser sustanciados de conformidad con las reglas del debido proceso legal, todo ello dentro de la obligación general estatal de garantizar el libre y pleno ejercicio de los derechos reconocidos por la Convención a toda persona que se encuentre bajo su jurisdicción. ${ }^{55}$

En consecuencia, la materialización u operancia del deber de investigar comporta ciertas particularidades según el tipo de violación de que se trate, por cuanto ello determina en cabeza de quién radica la activación del recurso: Estado o víctima. Así, cuando la afectación se identifica con violaciones graves a derechos humanos ${ }^{56}$ es un principio de derecho internacional que el Estado debe iniciar una investigación ex officio y sin dilación alguna, seria, imparcial y efectiva $^{57}$ que desemboque en procedimientos judiciales, que permitan la amplia participación de víctimas y familiares a fin de ser escuchados, tanto en el esclarecimiento de los hechos, la sanción de los responsables, y la búsqueda de una justa compensación. ${ }^{58}$

53.-Según la Corte, son leyes de aplicación inmediata aquellas que menoscaban derechos humanos por su mera expedición. Cfr. CrIDH, Responsabilidad Internacional por Expedición y Aplicación de Leyes Violatorias de la Convención (arts. 1 y 2 Convención Americana sobre Derechos Humanos), Opinión Consultiva OC-14/94 del 9 de diciembre de 1994, Serie A No. 14 , párr. 41.

54.- Cfr. CrIDH, Caso Palamara Iribarne, Sentencia de 22 de noviembre de 2005, Serie C No. 135, párr. 184; Caso de las Hermanas Serrano Cruz, Sentencia de 01 de marzo de 2005, Serie C No. 120, párr. 75.

55.-Cfr. CrIDH, Caso de la Comunidad Moiwana, Sentencia 15 de junio de 2005, Serie C No. 124, párr. 142; y, Caso 19 Comerciantes, ob. cit. párr. 194.

56.-Es claro que en materia de derechos humanos, no existen diferencias de grado o importancia en cuanto al derecho vulnerado, pues todos se ubican en el mismo plano de protección. La expresión se refiere a la violación de aquellos derechos como la vida, el cual es prerrequisito necesario para el goce de todos los demás derechos, pero adicionalmente, aquellas violaciones que se dan en contextos de violaciones sistemáticas o particularmente preocupantes como masacres, desapariciones forzadas, torturas, ejecuciones sumarias, desplazamiento forzado, u otras de similar calado.

57.-Cfr. CrIDH, Caso de los Hermanos Gómez Paquiyauri, Sentencia de 8 de julio de 2004, Serie C No. 110, párr. 131.

58.-Caso Myrna Mack Chang, Sentencia de 25 de noviembre de 2003, Serie C No. 101, párr. 157. 
Por ello la obligación de investigar ha de cumplirse con seriedad y no como una simple formalidad condenada de antemano a ser infructuosa. Debe tener un sentido y ser asumida por los Estados como un deber jurídico propio y no como una simple gestión de intereses particulares, sin que la autoridad pública busque efectivamente la verdad ${ }^{59}$, por lo que ante supuestos de violación grave como se indicó, la activación del dispositivo recae indudablemente sobre el poder estatal.

Si bien el recurso efectivo es reconocido como una acción sencilla y rápida de carácter fundamentalmente judicial por medio de la cual se puede acudir en búsqueda de la justicia (infra), en lo atinente a las investigaciones de oficio (generalmente relacionadas con la esfera penal) es preciso registrar que la existencia de tal dispositivo connota, además, una clara relación frente a la tipificación de determinados delitos en el derecho interno de los Estados, pues ante la ausencia de un referente penal que se corresponda con los supuestos de hecho de una violación en un caso particular, como por ejemplo la desaparición forzada $^{60}$, resultaría impróspera cualquier investigación.

Contrario sensu, cuando la violación no encarna un agravio particularmente delicado, será obligación del Estado disponer de recursos eficaces y accesibles a los presuntos lesionados, aunque no a ejecutarlos, pues en estos casos los interesados son los llamados a accionar tales mecanismos. ${ }^{61}$

En síntesis la gran obligación del Estado en la materia discutida, se centra en la existencia de recursos efectivos y el cumplimiento del debido proceso legal internacional (bajo toda circunstancia y momento), siendo que la diferencia operacional de los mismos recae en quién deba accionarlos, lo cual implica distintos niveles de exigencia. Su efecto práctico repercute por un lado, precisamente en las acciones que debe tomar el Estado de manera general y frente a violaciones específicas, y por otro, ante el procedimiento internacional, por lo cual resulta necesario estudiar estos dos derechos de manera separada pese su cercanía.

\subsubsection{Recurso efectivo}

Caracterizado por su sencillez, rapidez y efectividad para contener violaciones a los derechos humanos y eventualmente prevenirlas, el recurso efectivo del artículo 25 es entendido como el derecho subjetivo de acción que regularmente se asocia al amparo u otros mecanismos expeditos como el habeas corpus $^{62}$ (O'Donell, 2004), que tiene por objeto la tutela de todos los derechos reconocidos en las constituciones y leyes de los Estados Parte y por la Convención. Su existencia no está determinada

59.-Cfr. CrIDH, Caso Albán Cornejo, Sentencia de 22 de noviembre de 2007, Serie C No. 171, párr. 62; Caso Zambrano Vélez y otros, Sentencia de 4 de julio de 2007, Serie C No. 166, párr. 120; y, Caso Cantoral Huamani y García, Sentencia de 28 de enero de 2008 , Serie C No. 176.

60.-En casos de graves violaciones a derechos humanos, resulta necesario que dentro del ordenamiento penal se encuentren tipificados los delitos que se correspondan con la conducta desplegada. Por ejemplo, cuando en el caso colombiano la desaparición forzada no se encontraba codificada, resultaba difícil encausar adecuadamente las investigaciones criminales, pues ante la ausencia del tipo, la comisión de la conducta no prescribía consecuencia jurídica alguna contraria al establecimiento del derecho interno, resultando impróspera cualquier investigación. Cfr. CrIDH, Caso Caballero Delgado ob. cit. párr. 44.

61.-La actitud procesal del interesado es determinante para el agotamiento de los recursos en sede interna bajo el tipo de violaciones indicadas. Si la acción adecuada (efectiva) para la atención de una presunta violación llegase a caducar o prescribir sin que el alegado lesionado la agotara correspondiéndole hacerlo, en principio no podría acudir ante la protección del Sistema Regional pues en tal caso no se cumpliría lo dispuesto en el artículo 46.1 Convencional, a menos que se cumpla con uno de los requisitos del artículo 46.2 referentes a la inexistencia del debido proceso al interior del país, se haya impedido materialmente al interesado acudir a la justicia 0 haya retardo injustificado en la decisión de los mencionados recursos, cfr. CrIDH, Caso Salvador Chiriboga, Sentencia de 01 de marzo de 2005, Serie CNo. 120; y, Caso Genie Lacayo, Sentencia de 29 de enero de 1997, Serie C No. 30.

62.- La Corte ha considerado que dada la importancia de los recursos de hábeas corpus y amparo el artículo 27.2 convencional prohíbe suspenderlos, pues además son la base para preservar la legalidad en una sociedad democrática. Cfr. CrIDH, Caso Tibi, Sentencia de 7 de septiembre de 2004, Serie C No. 114, párr. 128; Caso Durand y Ugarte, Sentencia de 16 de agosto de 2000 , Serie C No. 68, párr. 106. 
únicamente por la previsión constitucional o legal, o por su aceptabilidad formal o general al interior de los ordenamientos, sino que requiere ser realmente idóneo para establecer si se ha incurrido en una violación a los derechos humanos y proveer lo necesario para remediarla, por lo tanto no pueden considerarse efectivos aquellos recursos que por las condiciones generales del país o incluso por las circunstancias particulares de un asunto dado, resulten ilusorios ${ }^{63}$, pues debe brindar la posibilidad real de interponer acciones que permitan alcanzar la protección judicial requerida. ${ }^{64}$

A pesar de lo anterior, su cumplimiento no se agota con la existencia de los derroteros mencionados. El Tribunal regional ha señalado que en todos los ordenamientos domésticos existen múltiples recursos, pero no todos son aplicables en cada situación, pues en casos específicos en los que determinado mecanismo no es adecuado, es obvio que no hay que agotarlo ${ }^{65}$; de igual manera, cabe la posibilidad de que todos los dispositivos disponibles en el derecho interno puedan, en determinadas circunstancias, satisfacer de una manera colectiva los requerimientos establecidos en el artículo 25 de la Convención, incluso si ninguno de ellos en lo individual cumple de una manera integral con dichas disposiciones. ${ }^{66}$

Tras advertir la existencia de los supuestos anteriores, la jurisprudencia del sistema interamericano en uso paulatino del artículo 8 de la Convención, ha reconocido algunas acciones como válidas para la materialización de este derecho, entre las que se cuentan los mecanismos propios de la jurisdicción administrativa en asuntos relacionados con restricciones aplicadas por el Estado en determinadas materias (por ejemplo en procesos de expropiación ${ }^{67}$ ), 0 las acciones de naturaleza constitucional para enjuiciar normas contrarias al Pacto $^{68}$; dispositivos que por su naturaleza, al igual que los recursos expeditos (supra), se encuentran caracterizados por el derecho subjetivo que contienen y en tal sentido, quedan a disposición de ser activados por el interesado.

Por el contrario cuando se trata de violaciones graves a los derechos humanos en la forma ya tratada supra, los recursos recién señalados carecen de eficacia pues el procedimiento llamado a prosperar en la mayoría de los casos es el de la justicia penal ordinaria, independiente de si los causantes de las conculcaciones son particulares 0 agentes del Estado. Ha manifestado la Corte que en los casos en que se ven involucrados representantes estatales, carecen de pertinencia procedimientos relacionados con la justicia penal militar, aquellos de carácter disciplinario ordinario, o de tipo administrativo, pues por regla general estos medios no están llamados a cumplir con los estándares fijados por el Sistema Interamericano $^{69}$, ya que en tratándose de infracciones inadmisibles, aún los procesos cursados ante la jurisdicción administrativa desvirtúan el reconocimiento de la responsabilidad del Estado por la violación a derechos humanos, dado que las decisiones arraigadas en esta sede atienden a teorías como el daño antijurídico y, en cualquier caso, no generan fielmente reconstrucción de la verdad histórica (Saffon \& Uprimny, 2007).

Así mismo, la Corte Interamericana considera que bajo supuestos fácticos de graves lesiones, el derecho a un recurso efectivo no se limita a las acciones promovidas por la víctima 0 sus

63.-Cfr. CrIDH, Opinión Consultiva OC-9/87, ob. cit. párr. 23.

64.-Cfr. CrIDH, Caso Acosta Calderón, Sentencia de 24 de Septiembre de 2009, Serie C No. 204, párr. 92; Caso de las Hermanas Serrano Cruz, ob. cit. párr. 75.

65.-Cfr. CrIDH, Caso Velásquez Rodríguez, ob.cit. párr. 64.

66.- Cfr. CrIDH, Masacre de Ituango, ob. cit. párr. 288. Cfr. TEDH, Caso Öneryildiz v. Turquía, No. 48939/99, Fallo de junio 18 de 2002 , párr. 100.

67.-Cfr. CrIDH, Caso Salvador Chiriboga, ob. cit.

68.-Un claro ejemplo de este tipo de recursos se observa en el ordenamiento constitucional colombiano con la Acción Pública de Inconstitucionalidad.

69.-Cfr. CrIDH, Caso de la Masacre de la Rochela, ob. cit. párrs. 199, y 217 a 225. 
derechohabientes, sino que comprende también un derecho a que el Estado investigue violaciones de los derechos humanos y, en la medida de lo posible, sancione penalmente a sus autores (O'Donell, 2004).

\subsubsection{Debido proceso}

En lo relacionado con este derecho, la Corte observa que la expresión garantías judiciales strictu sensu, se refiere a los medios procesales que sirven para proteger, asegurar 0 hacer valer la titularidad 0 ejercicio de un derecho, vale decir, los medios idóneos para que los derechos y libertades sean efectivos en toda circunstancia. ${ }^{70}$

El artículo 8 de la Convención previene un amplio conjunto de garantías que deben ser observadas durante la ejecución de todo procedimiento con independencia a la instancia del poder público en la que se desarrolle. Él deriva así mismo una amplia carga proteccionista en relación con la sustanciación de causas penales (numerales 2, 3, 4 y 5), postura que va de la mano con las garantías propias de carácter procesal contenidas en el derecho a la libertad personal del artículo 7 convencional ${ }^{71}$, por la importancia del postulado que se debate: la libertad (O'Donell, 2004); estándares que según criterios relativamente recientes de la jurisprudencia regional, podrán ser aplicados igualmente en procedimientos sancionatorios de índole administrativo ${ }^{72}$, en los que se deberán observar los elementos que componen el debido proceso convencional general a saber: a) derecho de defensa (ser oído); b) debido proceso (debidas garantías o defensa); c) juez natural (tribunal competente, independiente e imparcial); $y$, d) plazo razonable.
Tales prerrogativas fueron advertidas con mayor claridad en la sentencia de fondo en el caso Baena Ricardo contra Panamá, la que marcó un hito en la interpretación de las garantías que deben surtirse en asuntos de carácter sancionatorio, independiente de si se trata de un proceso penal o no, pues a propósito, el debate fáctico del asunto referenciado giró en torno a la aplicación de normas con fines de destitución laboral de 270 empleados $^{73}$. Esta postura es igualmente reflejada en el caso Ricardo Canese contra el Paraguay ${ }^{74}$, en el cual se aplica una medida restrictiva impidiendo la salida del país al señor Canese Krivoshein, situación que es considerada como sancionatoria. En ambos casos la Corte indicó que las sanciones administrativas son, como las penales, una expresión del poder punitivo del Estado y que tienen, en ocasiones, naturaleza similar a la de éstas[,] [pues] [u]nas y otras implican menoscabo, privación o alteración de los derechos de las personas, como consecuencia de una conducta ilícita.

Si bien los estándares indicados se produjeron bajo el contexto analítico sobre la expedición y/o aplicación de normas violatorias del principio de Legalidad y de Retroactividad del artículo 9 convencional, ello no es óbice para que dichos derroteros puedan ser aplicados al campo de las garantías del artículo 8, pues de la práctica de los Estados se desprende la existencia de normas administrativas de carácter sancionatorio, que se aplican mediante procedimientos administrativos 0 bajo la jurisdicción administrativa como sucede en el campo de la inmigración ${ }^{75}$. A pesar de ello, habrá que analizar con extremo cuidado las características particulares del caso al que se pretenda dar aplicación de estándares más elevados, pues es incipiente la producción sobre la materia y por tal

70.-Cfr, CrIDH, Opinión Consultiva OC-9/87, ob. cit. párrs. 27 y 28.

71.-Artículo 7.5 y 7.6 de la CADH

72.-Cfr. CrIDH, Caso Baena Ricardo Panamá, Sentencia de 2 de febrero de 2001, Serie C No. 72, párr. 106.

73.- Ibid, párr. 88.

74.-Cfr. CrIDH, Caso Ricardo Canese, Sentencia de 31 de agosto de 2004, Serie C No. 111, párr. 176.

75.-En materia de inmigración, la Corte no ha tenido la oportunidad de pronunciarse por vía contenciosa en relación a un asunto particular, pero existen precedentes jurisprudenciales de la $\mathrm{CIDH}$ sobre la materia, pues tal fenómeno es una realidad mundial que no escapa a la situación americana, con un particular acento en el caso estadounidense. Cfr. CIDH, Informe No. 78/09, Petición 478-05, Admisibilidad, Migrantes indocumentados, residentes legales y ciudadanos estadounidenses víctimas de vigilantes anti-inmigrante, 5 de agosto de 2009. 
razón dichos pronunciamientos no se pueden considerar precedentes decantados y en consecuencia vinculantes en forma general.

De cualquier manera, a pesar de la prolífica jurisprudencia universal y regional en torno a cada una de las posibles situaciones en que opera este derecho, resulta útil realizar una enumeración de los diferentes factores que inciden su desarrollo: a) el derecho a ser oído públicamente por un juez competente, independiente e imparcial en el campo de tribunales ordinarios (la competencia del tribunal, la independencia del tribunal, la publicidad del proceso, la independencia e imparcialidad del Ministerio Público); b) los tribunales especiales y militares; c) la presunción de inocencia; d) la exclusión de confesiones y declaraciones involuntarias; e) la asistencia letrada (durante el interrogatorio, derecho a defensor de elección por el procesado, derecho a un defensor de oficio, derecho a comunicarse con su defensor, derecho a representación eficaz, derecho a defenderse personalmente); f) el derecho al tiempo y a los medios necesarios para preparar la defensa (el derecho a ser informado de los cargos, el derecho al tiempo adecuado para la preparación de la defensa, el derecho a los medios adecuados para la preparación de la defensa); g) el derecho a presentar testigos y contrainterrogar testigos de cargo (la igualdad de las partes, el derecho a hallarse presente, el derecho a un intérprete, el derecho de apelación); h) el derecho de la persona a ser oída sin demora; i) el principio de legalidad; j) el non bis in idem; k) procedimientos relativos a la modificación de una sentencia; y, I) el derecho de ciertas comunidades a un trato especial, como es el caso de los adolescentes infractores, el derecho de los niños y niñas, el derecho de los afrodescendientes, de los indígenas o de los inmigrantes (O'Donell, 2004; Rodríguez Rescia, 1998).

Al tener en cuenta que el enfoque a las garantías judiciales obedece al deber de investigar, en el marco de las obligaciones de atender, resulta necesario realizar algunas observaciones generales en lo relacionado al juez natural y el plazo razonable, pues éstos representan una importancia significativa tras la búsqueda de la verdad o la justicia por parte de los Estados en casos de graves violaciones a los derechos humanos, ante su compromiso con los artículos 8 y 25 convencionales.

\subsubsection{Juez natural}

El juez natural ha sido tema de interesantes disertaciones, a propósito de la finalidad de los tribunales especiales cuando adelantan investigaciones relacionadas con violaciones graves a los derechos humanos, tal como sucede con la justicia penal militar $^{76}$. De igual manera ha sido objeto de análisis ante la determinación de los derechos del niño ${ }^{77}$, o en aspectos relacionados con los derechos de los inmigrantes ${ }^{78}$, por ejemplo.

Generalmente, el concepto de juez natural se refiere a la obligación de adelantar procedimientos ante tribunales constituidos previamente por la ley, debidamente investidos para la determinación de derechos y obligaciones demandados ante su conocimiento. Tal condición previene el cumplimiento de al menos dos requerimientos: a) que el juez se encuentre preestablecido por la ley ${ }^{79}$ con la

76.-Para una mejor referencia, ver las sentencias de fondo relacionadas con los casos colombianos: Las Palmeras, 19 Comerciantes, Masacres de Mapiripán, Masacres de Ituango, Masacre de Pueblo Bello, Masacre de la Rochela y Escué zapata. Así mismo, las sentencias de los casos mexicanos Rosendo Cantú y Otra, Sentencia de 31 de agosto de 2010, Serie C No. 216, párr. 156 y ss.; y, Cabrera García y Montiel Flores, Sentencia de 26 de noviembre de 2010, Serie C No. 220, las cuales sientan la doctrina jurisprudencial latinoamericana sobre el particular.

77.- Cfr. CrIDH, Caso Molina Theissen, Sentencia de 4 de mayo de 2004, Serie C No. 106; Caso Servellón García, Sentencia de 21 de septiembre de 2006, Serie C No. 152; Condición Jurídica y Derechos Humanos del Niño, Opinión Consultiva OC-17/02 del 28 de agosto de 2002, Serie A No. 17.

78.-Cfr. CrIDH, Opinión Consultiva OC-16/99, ob. cit.

79.-Existen excepciones en casos relativos a procesos de justicia transicional como ha ocurrido con las normas que crearon y regulan el ejercicio del TPIR, o en casos recientes con la Ley de Justicia y Paz para el caso colombiano. 
asignación de competencias para el tratamiento de determinados derechos, y b) que dichas competencias sean legítimamente adjudicables ${ }^{80}$, para lo cual resulta importante referirse a los procesos ante fueros castrenses 0 de carácter disciplinario.

En la sentencia de fondo en el caso relacionado con la Masacre de Mapiripán contra Colombia, la Corte reiteró con respecto a la justicia penal militar que en un Estado democrático de derecho dicha jurisdicción ha de tener un alcance restrictivo y excepcional y estar encaminada a la protección de intereses jurídicos especiales, vinculados con las funciones que la ley asigna a las fuerzas militares. Por ello, sólo se debe juzgar a militares por la comisión de delitos o faltas que por su propia naturaleza atenten contra bienes jurídicos propios del orden militar ${ }^{81}$, entre los cuales bajo ninguna circunstancia han de suscribirse los relacionados con graves violaciones a los derechos humanos.

Mediante un pronunciamiento anterior contra el mismo Estado, ya había recalcado que la jurisdicción militar reserva su aplicación a los militares que hayan incurrido en delito o falta dentro del ejercicio de sus funciones y bajo determinadas condiciones, por lo que cuando la justicia militar asume competencia sobre un asunto que debe conocer la justicia ordinaria, se ve afectado el derecho al juez natural y a fortiori, el debido proceso, el cual a su vez, se encuentra íntimamente ligado al propio derecho de acceso a la justicia. ${ }^{82}$

A su turno, cuando se trata de procedimientos disciplinarios ordinarios ocurre una situación similar, pues según la jurisprudencia, una investigación de tal naturaleza tiende a la protección de la función administrativa y la corrección y control de los funcionarios públicos, por lo que puede complementar pero no sustituir a cabalidad la función de la jurisdicción penal en casos graves de violaciones a derechos humanos. ${ }^{83}$

\subsubsection{Plazo razonable}

Por su parte, el plazo razonable se refiere al lapso perentorio, prudente y necesario, comprendido entre, la iniciación de una causa o el conocimiento de un hecho objeto de investigación por el poder público y/o el inicio de los procedimientos judiciales por parte de la víctima tendientes a restablecer derechos, y el momento en que se resuelve materialmente la situación.

La sentencia de fondo, reparaciones y costas sobre el caso Genie Lacayo vs Nicaragua ${ }^{84}$, determinó en forma general el límite de 5 años como plazo suficiente para la sustanciación de procesos en sede interna ${ }^{85}$ y fijó elementos de interpretación respecto

80.-La competencia no queda corroborada por la naturaleza de la norma o su existencia en el mundo jurídico, sino que los funcionarios encargados de sustanciar determinados derechos deben cumplir con requerimientos especiales. Un ejemplo claro se encuentra en relación con los derechos de los niños, pues las Reglas Mínimas para la Administración de Justicia de Menores de la ONU conocidas como Reglas de Beijing de 1985, exponen la necesidad de cumplir requisitos más elevados a los funcionarios que determinan los derechos de esta población, preceptos que aún pertenecientes al campo del soft law, han sido acogidos por la Corte Interamericana en la sustanciación de estos derechos, como se desprende de la Opinión Consultiva OC-17/02.

81.- $\mathrm{CrIDH}$, Caso de la Masacre de Mapiripán, ob. cit. párr. 202; Caso 19 Comerciantes, ob. cit. párr. 165.

82.-Cfr. CrIDH, Caso Cantoral Benavides, Sentencia de 18 de agosto de 2000, Serie C No. 69, párr. 112; y, Caso Castillo Petruzzi y otros, Sentencia de 30 de mayo de 1999, Serie CNo. 52, párr. 128.

83.- $\mathrm{CrIDH}$, Caso de la Masacre de Pueblo Bello, ob. cit. párr. 203.

84.-Cfr. CrIDH, Caso Genie Lacayo, ob. cit. párr. 77.

85.-Este lapso varía según el derecho de que se trate, pues existen diversas situaciones en las que un periodo considerablemente inferior podrá ser irrazonable. Por ejemplo, la privación de la libertad que exceda determinadas horas podrá convertirse en arbitraria y traspasar el límite de lo permitido; de otro lado actuaciones ante autoridades administrativas también se deberán ajustar a plazos infinitamente inferiores, los cuales se adecuarán a cada caso específico; así mismo será posible que ante instancias contencioso administrativas el periodo deba ser menor. Una mejor referencia podrá ser abordada en: Comisión Interamericana de Derechos Humanos. El Acceso a la justicia como garantía de los derechos económicos, sociales y culturales. Estudio de estándares fijados por el Sistema Interamericano de Derechos Humanos. OEA/Ser.L/V/II.129 Doc. 4, 7 septiembre 2007, Washington D.C. 
del cumplimiento de tal estándar en un caso específico, tras observar que para ello es necesario tener en cuenta tres elementos: a) la complejidad del asunto; b) la actividad procesal del interesado; y c) la conducta de las autoridades judiciales ${ }^{86}$, lo cual fuera complementado por un cuarto elemento denominado d) afectaciones a la víctima (condición jurídica en que se encuentra la víctima), como un desarrollo jurisprudencial adelantado por el Juez Mexicano Sergio García Ramírez.

En relación con la complejidad, resulta preciso observar el nivel de dificultad de los distintos asuntos que han originado afectaciones a la persona, pues no será lo mismo investigar la ocurrencia de una masacre en principio atribuible a terceros particulares con apoyo de agentes del Estado, bajo contextos de inoperancia de la justicia y falta de independencia del poder jurisdiccional, a las averiguaciones relacionadas con la privación arbitraria de la libertad personal, 0 al reconocimiento de ciertos derechos económicos sociales y culturales.

A su turno, habrá momentos en los cuales la actividad procesal del interesado es determinante para la activación de los recursos, el impulso procesal de las causas y su consecuente solución de fondo, mientras que en otras circunstancias esta condición pierde importancia, como sucede ante hechos que requieren ser investigados por decisión estatal, situaciones en las cuales la búsqueda efectiva de la verdad corresponde al Estado y no depende de la iniciativa procesal de la víctima o de sus familiares, 0 de la aportación privada de elementos probatorios. ${ }^{87}$
Respecto del tercer elemento, será necesario observar y analizar la conducta de las autoridades desde la comisión de los actos violatorios, lo cual implica revisar en detalle el desarrollo procesal, así como la identificación de todas las actuaciones realizadas desde que el Estado conoció de las infracciones, con el ánimo de determinar si en el caso objeto de estudio éstas han sido asumidas en forma dilatoria o con poca seriedad ${ }^{88}$, pues habrá que tener en cuenta que los artículos 8 y 25 de la Convención concretan, con referencia a las actuaciones y omisiones de los órganos judiciales internos, los alcances del principio de generación de responsabilidad por los actos de cualquiera de los órganos del Estado. ${ }^{89}$

De acuerdo al anterior análisis, se entiende que la obligación de investigar debe aportar valiosos insumos para la satisfacción de las víctimas, tras la consecución de la verdad judicial y en tanto histórica, así como la sanción a los responsables de las alegadas violaciones cuando se trata de aquellos casos graves. Bajo otros supuestos, el aparato estatal mediante su conducta debe amparar materialmente al afectado, pues al establecer la responsabilidad internacional del Estado con motivo de la violación a los derechos humanos consagrados en los artículos 8.1 y 25 de la Convención Americana, un aspecto sustancial de la controversia ante la Corte no es si en el ámbito interno se emitieron sentencias o se llegó a acuerdos conciliatorios por responsabilidad administrativa de un órgano estatal, o civil entre particulares, sino si los procesos internos permitieron que se garantizara un verdadero acceso a la justicia conforme a los estándares previstos en el citado instrumento; a pesar de ello, tales decisiones pueden ser tenidas en cuenta en materia de reparación pecuniaria. ${ }^{90}$

86.-En idéntico sentido se ha pronunciado el TEDH en los Casos Ruiz Mateos v. España, Fallo del 23 de junio de 1993, Serie A No. 262, párr. 30; y, Motta v. Italia, Fallo del 19 de febrero de 1991, Serie A No. 195-A, párr. 30.

87.- Cfr. CrIDH, Caso Baldeón García, Sentencia de 6 de abril de 2006, Serie C No. 147, párr. 93.

88.-En el caso de la Masacre de Ituango contra Colombia la Corte manifestó que la negligencia de las autoridades judiciales encargadas de examinar las circunstancias de los actos lesivos, mediante la recolección oportuna de pruebas in situ, no puede ser subsanada con las tardías diligencias probatorias iniciadas en las investigaciones, pues tales insuficiencias pueden ser calificadas como graves faltas al deber de investigar los hechos ocurridos, y en consecuencia desconocen la efectiva determinación de éstos. Cfr. $\mathrm{CrIDH}$, Caso de las Masacres de Ituango, ob. cit. párr. 316.

89.- Cfr. Caso "Niños de la Calle" (Villagrán Morales), Sentencia de 19 de noviembre de 1999, Serie C No. 63, párr. 220; Caso Ximenes Lopes, Sentencia de 4 de julio de 2006, Serie C No. 149, párr. 173.

90.-CorteIDH, Caso Manuel Cepeda Vargas vs Colombia, Sentencia de 26 de mayo de 2010, Serie C No. 213, párrs. 245 y 246. 
Por ello, el derecho a las garantías judiciales no se agota con el trámite de procesos internos, pues el mismo exige intrínsecamente que se asegure el derecho de las presuntas víctimas o sus familiares, a que se haga todo lo necesario para conocer la verdad de lo sucedido y sancionar a los responsables en un tiempo razonable cuando sea su caso ${ }^{91}$, pues bajo cualquier presupuesto de violación, la debida diligencia exige que el órgano que investiga lleve a cabo todas aquellas actuaciones y averiguaciones necesarias para procurar el resultado que se persigue, pues de otro modo, la investigación no es efectiva en los términos de la Convención. ${ }^{92}$

Así debe reconocerse que en el campo de las obligaciones de medio (concepto cercano al deber de investigar), la "debida diligencia" implica una complejidad tal, que aun cuando su incumplimiento no se demuestra por la mera disposición de que un derecho haya sido violado ${ }^{93}$, a efectos de la determinación de responsabilidad internacional de los Estados Parte, resulta necesario el cumplimiento de un estándar bastante elevado o de diligencia máxima regida por las consideraciones expuestas, de forma tal que el aforismo obligación de comportamiento, resulta bastante minimizado en la esfera del Sistema Regional.

Pese el amplio estándar internacional sobre acceso a la justicia en materia de investigación, lo que incluye la prohibición de amnistías, no es claro en este momento cuáles son sus límites en los procesos de justicia transicional, aunque la reciente sentencia de las Masacres de el Mozote haya insistido en que la justicia en estos procesos no es especial y por tanto no exime el deber de investigación, verdad y reparación para las víctimas ${ }^{94}$, lo que al ser confrontado con la idea de ponderación de medidas propuesto en el voto concurrente de la decisión ${ }^{95}$ (teoría que en lo mínimo es novedosa), al ser abordada en abstracto la misma poco aporta a la discusión, pues las miles de páginas que conforman los textos sobre justicia transicional ya se han referido en términos generales y abstractos sobre la necesidad de ponderar.

\subsubsection{Obligación de reparar}

Tal como sucede con las otras materias sujetas a conocimiento de la Corte Interamericana de Derechos Humanos y dirimidas por ésta, la de las reparaciones asiente un fuerte contenido de precedente jurisprudencial, arraigado en un principio, en decisiones tomadas por tribunales internacionales como en el caso Factory at Chorzow ${ }^{96}$ fallado por la otrora Corte Permanente de Justicia Internacional, o en la Opinión Consultiva sobre Reparations for Injuries in the Service of the United Nations ${ }^{97}$ de la CIJ, así como en precedentes del Tribunal Europeo; y en postrimería, a partir del desarrollo emitido bajo sus propios antecedentes.

Al igual que la obligación de investigar, la de reparar se genera ante el incumplimiento general y primario de proteger los derechos humanos como se señaló al inicio de las obligaciones de garantía, y por tal razón, la misma se rige en todos sus aspectos por el derecho internacional, es decir, que los tribunales encargados de fijarla tendrán en cuenta su alcance, naturaleza, modalidades de cumplimiento, así como la determinación de los beneficiarios, nada de lo cual puede ser modificado por el Estado obligado

91.-Cfr. CrIDH, Caso de las Hermanas Serrano Cruz, ob. cit. párr. 66; Caso 19 Comerciantes, ob. cit. párr. 188.

92.-Cfr. CrIDH, Caso Gómez Palomino, Sentencia de 22 de noviembre de 2005. Serie C No. 136, párr. 80.

93.- Cfr. CrIDH, Caso Velásquez Rodríguez, ob. cit. párr. 175.

94.-Corte IDH, Caso Masacres de El Mozote y lugares aledaños vs El Salvador, Sentencia de 25 de octubre de 2012, Serie C No. 252.

95.-CortelDH, Caso Masacres de El Mozote y lugares aledaños, Voto Concurrente Juez Diego García Sayán, párrs. 25, 27,28 y 38.

Cfr. CrIDH, Caso de la Masacre de Mapiripán, ob cit. párr. 315.

96.-Cfr. CPII, Caso Relativo a la Fábrica de Chorzow (Solicitud de Indemnización) Fallo de Jurisdicción o Competencia No. 8, 1927, Serie A No. 9, pág. 21, y Fallo de Mérito o Fondo No. 13, 1928, Serie A No. 17, pág. 29.

97.-Cfr. CIJ, Reparaciones por Lesiones Sufridas en el Servicio de Naciones Unidas, Opinión Consultiva, Abril 11 de 1949 , pág. 184. 98.- Cfr. CrIDH, Caso Neira Alegría y otros, Sentencia de 19 de septiembre de 1996, Serie C No. 29, párr. 36; Caso Garrido y Baigorria, Sentencia de 27 de agosto de 1998, Serie C No. 39, párr. 40. 
invocando para ello disposiciones de su derecho interno, pues la finalidad de estas medidas es trasladar a la víctima al estado anterior a la conculcación o en su defecto hacer desaparecer los efectos de las violaciones cometidas (García Ramírez, 2005).

Ha decantado la Corte que la reparación es el término genérico que comprende las diferentes formas como un Estado puede hacer frente a la responsabilidad internacional en que ha incurrido, desde el enfoque de la restitutio in integrum, lo cual incluye la indemnización por daños materiales, la compensación en equidad del daño moral, las medidas de satisfacción, las garantías de no repetición y otras más que imprimen un valor cualitativamente ejemplificante (Saavedra Alessandri, 2004).

Las referidas consideraciones han permitido que la Corte ordene medidas de reparación distintas a lo económico, que no solo repercuten sobre las víctimas directas e indirectas de las violaciones ocurridas, sino que inciden en el colectivo social como se deriva de ciertas acciones fijadas en el marco de las garantías de no repetición. Para ello se debe tener en cuenta tanto los sufrimientos y las aflicciones causadas a las víctimas directas y sus allegados, así como el menoscabo de valores muy significativos para las personas, lo cual puede hacerse de dos maneras: la primera mediante el pago de una cantidad de dinero y la segunda mediante la realización de actos $u$ obras de alcance 0 repercusión públicos, y del compromiso con los esfuerzos tendientes a que situaciones similares no vuelvan a ocurrir, que tengan como efecto la recuperación de la memoria de las víctimas así como el reconocimiento de su dignidad. ${ }^{99}$

En el marco de éstas, la Corte Interamericana ha fijado acciones variadas tendientes a revertir 0 compensar las violaciones y a suprimir las fuentes del menoscabo, por medio de maniobras como la investigación y sanción adecuada a los responsables de las violaciones ${ }^{100}$; la realización de actos públicos de reconocimiento de responsabilidad y ofrecimiento de disculpas por tales hechos ${ }^{101}$; la construcción de monumentos, plazas, parques, escuelas y otras similares $^{102}$; la fundación de organizaciones para la promoción y protección a derechos humanos ${ }^{103}$; la formación de comisiones temporales de seguimiento al cumplimiento de las sentencias ${ }^{104}$; la disposición de medidas sociales, médicas, educativas, de salud, de seguridad y otras tendientes a proteger a grupos poblacionales afectados ${ }^{105}$; la capacitación en derechos humanos a miembros de la fuerza pública y funcionarios estatales como política de Estado ${ }^{106}$; el ajuste de determinada normatividad interna a los estándares previstos por la $\mathrm{CADH}^{107}$; entre otras.

No queda claro igualmente, si la falta de reparación pueda constituir una causal autónoma de responsabilidad internacional. Ya se vio en el Caso Manuel Cepeda Vargas que a pesar de haberse reparado económicamente en derecho interno, si deberes como el de investigar no se han cumplido cabalmente el trámite internacional puede ser activado. A pesar de ello, no se sabe si casos contrarios podrían convertirse en causa internacional, es decir, aquellos en los que se hayan cumplido las otras obligaciones excepto la de reparar puedan llegar ante conocimiento de la Corte.

99.-CrIDH, Caso Caesar, Sentencia 11 de marzo 2005, Serie C No. 123, párr. 125; y, Caso Huilca Tecse, Sentencia de 03 de marzo de 2005, Serie CNo. 121, párr. 96.

100.-Cfr. CrIDH, Caso Carpio Nicolle, Sentencia de 22 de noviembre 2004. Serie C No. 117, párr. 128; y, Caso de los Hermanos Gómez Paquiyauri, ob. cit. párr. 261.

101.-Cfr.CrIDH, Caso Kawas Fernández, ob. cit. párr. 202.

102.-Cfr. CrIDH, Caso La Cantuta, ob. cit. párr. 236.

103.-Cfr. CrIDH, Caso Aloeboetoe y otros, Sentencia de 10 de septiembre de 1993, Serie C No. 15, párr. 103.

104.-Cfr. CrIDH, Caso de la Masacre de Mapiripán, ob cit. párr. 315.

105.-Caso del Penal Miguel Castro Castro, ob. cit. párr. 448.

106.-Cfr. CrIDH, Caso de las Masacres de Ituango, ob. cit. párr. 409.

107.-Cfr. CrIDH, Caso González y otras (Campo Algodonero), ob. cit. párrs. 497, 513, 521 y 526. 


\subsubsection{Deber de adoptar disposiciones de Derecho Interno}

La jurisprudencia de la Corte Interamericana ha querido dar una importancia significativa a la obligación derivada del contenido citado en el artículo 2 de la Convención, aunque la interpretación prevista sobre dicha regla sea bastante consecuente con su contenido literal, tras entender que la aplicación de este artículo coadyuva o, en el mejor de los casos, materializa el cumplimiento de las obligaciones previstas en el artículo 1.1.

Tal mandato involucra la implementación de medidas de diferente naturaleza. En consecuencia, por una parte advierte la necesidad de introducir normas y el desarrollo de prácticas conducentes al efectivo complimiento de las garantías previstas en la Convención, mientras que por otra implica la supresión de reglas y conductas de cualquier naturaleza que entrañen una violación a dichas garantías. ${ }^{108}$

Obsérvese que el mandato general impuesto por este artículo no se refiere en forma exclusiva a la norma jurídica, si no que por el contrario alude a cualquier acción que el Estado adopte en su ordenamiento estatal. Tampoco enfatiza o restringe el tipo de medida, es decir, se trata indistintamente de cualquier mecanismo destinado a prevenir, atender, investigar, sancionar o reparar en forma individual o en conjunto, entre las cuales bien se incluyen las de tipo estructural, social o cultural (normas jurídicas, sociales o culturales).

Éstas no solo deberán atender la relación entre el Estado y las personas sujetas a su jurisdicción, sino que sus efectos han de proyectarse más allá de la relación entre el poder público o sus representantes y los individuos, tras recoger y cumplir la obligación positiva del Estado de adoptar todas las medidas necesarias para asegurar la efectiva protección de los derechos humanos en las relaciones entre los particulares como se subrayó supra, las cuales patrocinan el cumplimiento de las obligaciones erga omnes y en consecuencia la garantía del efecto útil de los tratados sobre derechos humanos ${ }^{109}$; es decir, que el respeto por estos derechos al interior del Estado Parte debe guiar toda conducta, no solo la del Estado y sus representantes, sino de las personas del común en sus relaciones cotidianas.

En el voto razonado sobre la Masacre de Mapiripán, el Juez Cançado Trindade valora la importancia de esta norma en el cuerpo de la Convención Americana, pues entiende que así como la existencia de una ley manifiestamente incompatible con la Convención acarrea per se una violación de ésta (bajo el deber general de su artículo 2, de armonización de la normativa de derecho interno), la falta de medidas positivas de protección -inclusive de carácter preventivo- acarrea per se una violación de la CADH en los términos del artículo 1.1. ${ }^{110}$ Esta situación ha sido reconocida en otras oportunidades por la Corte Interamericana, tras entender adicionalmente que el menoscabo a los deberes generales no se encuentra subsumido en violaciones individuales de derechos específicos a la luz del Pacto, sino que más bien aquel se suma a dichas infracciones. ${ }^{111}$

A pesar de la simplicidad en la lógica de estos argumentos, ellos han dado lugar a modificaciones de la norma constitucional como sucedió en el caso de la Última Tentación de Cristo vs Chile, lo que dio inicio a la teoría del control de convencionalidad, y aunque la misma no es plenamente aceptada por los Estados, lo que ha producido una fuerte

108.-Cfr. CrIDH, Caso Lori Berenson, Sentencia de 25 de noviembre de 2004, Serie C No. 119, párr. 219; Caso Instituto de Reeducación del Menor, Sentencia de 2 de septiembre de 2004, Serie C No. 112, párr. 206.

109.-Cfr. CrIDH, Caso Cantos, ob. cit. párr. 59; Caso Hilarie, Constantine y Benjamin y otros, Sentencia de 21 de junio de 2002 , Serie C No. 94, párr. 213.

110.- CrIDH, Caso de la Masacre de Mapiripán, ob. cit. Voto Razonado Juez Cançado Trindade, párr. 6.

111.-Cfr. CrIDH, Caso Cinco Pensionistas, Sentencia de 28 de febrero de 2003, Serie C No. 98; Caso Baena Ricardo y otros, ob. cit.; Caso Castillo Petruzzi y otros, ob. cit. 
resistencia bajo la égida de la soberanía del derecho constitucional, la misma ha evolucionado conceptualmente en otros casos fallados por el mismo tribunal interamericano. ${ }^{112}$

\section{CONCLUSIÓN}

Los deberes internacionales que sobre derechos humanos han adquirido los Estados, se fundamentan en la obligación negativa de respeto y la positiva de garantía, que para el caso de la Convención Americana se encuentran consignadas en el artículo 1.1. Ellas han sido igualmente establecidas en otros instrumentos internacionales como la Declaración Universal de Derechos Humanos (preámbulo) el Pacto Internacional de Derechos Civiles y Políticos (artículo 2) y el Pacto Internacional de Derechos Económicos Sociales y Culturales (artículo 2), siendo que la diferencia entre el Pacto de San José de Costa Rica y la Carta de Derechos Humanos ${ }^{113}$ está determinada por la exigibilidad que representó en el momento histórico de su creación, aunque en la actualidad esta última es considerada por los órganos internacionales competentes, manifestaciones del derecho internacional consuetudinario.

El desarrollo jurídico de tales compromisos, ha trasegado en dirección de ratificar su importancia en el cumplimiento efectivo de todos los derechos consagrados en el cuerpo normativo de los respectivos tratados como la $\mathrm{CADH}$, pues por una parte previene las obligaciones de prevenir y atender, las cuales se cumplen mediante la implementación de diferentes acciones a cargo del Estado (no solo legales sino de alcance político, social o cultural), y por otra, reclama su incumplimiento por medio de la responsabilidad internacional de los Estados infractores, a través de un entendimiento sui generis sobre la responsabilidad en los marcos de los Sistemas de Protección.
Dicha exigencia reivindica las obligaciones de adoptar disposiciones de derecho interno del artículo 2 y el de las reparaciones previstas en el artículo 63.1 convencional, que en el ámbito internacional han permitido grandes avances en la protección a los derechos humanos en ciertos aspectos, pero latentes preocupaciones en otros, como se refleja en las violaciones de tipo sistemático-estructural a derechos humanos relativas al caso colombiano, sin que el amplio alcance interpretativo y la intervención internacional hayan sido determinantes para corregir las causas de las conculcaciones cuando provienen del Estado.

Así las cosas, el análisis de las obligaciones generales realizado por la Corte IDH va más allá de la interpretación judicial. Si bien dichos estándares obedecen rectoralmente a consideraciones de tipo jurídico, ello no desestima la fuerza con la que traza la conducta ideal del aparato estatal en relación con los individuos sujetos a su jurisdicción, pues como bien se nota en diferentes momentos, las directrices jurídicas y convencionales no se dirigen exclusivamente a la adecuación normativa de los ordenamientos jurídicos 0 al cumplimiento de obligaciones gaseosas, sino que trascienden a la ejecución de acciones de otro tipo.

Igualmente un importante número de dudas 0 reflexiones surgen en este análisis, los cuales se pueden relacionar al menos con: a) cuál o cuáles son las bases teóricas admisibles de la responsabilidad ante el Sistema Interamericano (teoría del riesgo creado, el papel de garante, responsabilidad por terceros, etc.); b) cuál es el papel que debe jugar el estándar internacional en materia de investigaciónsanción durante procesos de justicia transicional (en términos conceptuales y temporales); c) la ausencia de reparación adecuada al estándar internacional es una causal autónoma para la declaratoria de responsabilidad internacional; y d) la recepción de la teoría del control de convencionalidad por parte del derecho constitucional interno.

112.-Cfr. CrIDH, Casos Almonacid Arellano y otros vs Chile, Sentencia de 26 de septiembre de 2006, Serie C No. 154; Trabajadores Cesados del Congreso (Aguado Alfaro y otros), Sentencia de 24 de noviembre de 2006, Serie C No. 158; Fernández Ortega y Otrs vs México, Sentencia de 30 de agosto de 2010, Serie C No. 215; Manuel Cepeda Vargas vs Colombia, Sentencia de 26 de mayo de 2010, Serie C No. 213; Caso Cabrera García y Montiel Flores; Caso Gelman vs Uruguay, Sentencia de 24 de febrero de 2011, Serie C No. 221.

113.- Se conoce como Carta de Derechos Humanos, conjuntamente a la Declaración Universal de Derechos Humanos, el PIDCP y el PIDESC. 


\section{ABREVIATURAS}

CADH o Pacto de San José de Costa Rica: ConvenciónAmericana sobre Derechos Humanos

CICR: Comité Internacional de la Cruz Roja

CIDH: Comisión Interamericana de Derechos Humanos

CIJ: Corte Internacional de Justicia

CPI: Corte Penal Internacional

CPJI: Corte Permanente de Justicia Internacional

CrIDH o Corte IDH: Corte Interamericana de Derechos Humanos

DDHH: Derechos Humanos

DESC: Derechos Económicos, Sociales y Culturales

DIDH: Derecho Internacional de los Derechos Humanos

DIH: Derecho Internacional Humanitario

OC: Opinión Consultiva

OEA: Organización de Estados Americanos

ONU: Organización de las Naciones Unidas

PIDCP: Pacto Internacional de Derechos Civiles y Políticos

PIDESC: Pacto Internacional de Derechos Económicos, Sociales y Culturales

SIDH: Sistema Interamericano de Derechos Humanos

TEDH: Tribunal Europeo de Derechos Humanos

TPIR: Tribunal Penal Internacional para Rwanda

TPIY: Tribunal Penal Internacional para la antigua Yugoslavia

\section{REFERENCIAS BIBLIOGRÁFICAS}

- Becerra Ramírez, M. (1998). Las Decisiones Judiciales como Fuente del Derecho Internacional de los Derechos Humanos. En $\mathrm{H}$. Fix-Zamudio, LiberAmicorum, Volúmen I (pp. 431-446). San José de Costa Rica: Corte Interamericana de Derechos Humanos y Unión Europea.

- Dworkin, R. \& H. L. A. Hart. (1997). La decisión judicial. El debate Hart - Dworking. Bogotá: Siglo del Hombre Editores Universidad de los Andes.

- Faúndez Ledesma, H. (2004). El Sistema Interamericano de Protección de los Derechos
Humanos. Aspectos institucionales y procesales. (pp. 31). San José de Costa Rica: Instituto Interamericano de Derechos Humanos.

- Feria Tinta, M. (2008). La responsabilidad internacional del Estado en el sistema interamericano de protección de derechos humanos a veinticinco años del funcionamiento de la Corte Interamericana de Derechos Humanos: las lecciones del caso Hermanos Gómez Paquiyauri. En Instituto de Investigaciones jurídicas UNAM, La Corte Interamericana de Derechos Humanos a 25 años de su funcionamiento (pp. 63-113). Disponible en: http://www.bibliojuridica.org/libros/ 5/2496/8.pdf. Consultado el 16 de enero de 2010.

- García Ramírez, S. (2005). La Jurisprudencia de la Corte Interamericana de Derechos Humanos en materia de reparaciones. En Corte Interamericana de Derechos Humanos, La Corte Interamericana de Derechos Humanos Un Cuarto de Siglo: 1979-2004 (pp. 1-85). San José de Costa Rica: Corte Interamericana de Derechos Humanos.

- García San Jose, D. I. (2001). Los derechos y libertades fundamentales en la sociedad europea del siglo XXI. Sevilla: Secretariado de Publicaciones Universidad de Sevilla.

- Medina Quiroga, C. (2005). Las Obligaciones de los Estados bajo la Convención Americana Sobre Derechos Humanos. En Corte Interamericana de Derechos Humanos, La Corte Interamericana de Derechos Humanos Un Cuarto de Siglo: 19792004 (pp. 207-270). San José de Costa Rica: Corte Interamericana de Derechos Humanos.

- O'Donell, D. (2004). Derecho Internacional de los Derechos Humanos. Normativa, Jurisprudencia y Doctrina de los Sistemas Universal e Interamericano (pp. 282-286, 911-974). Bogotá: Oficina en Colombia del Alto Comisionado de las Naciones Unidas para los Derechos Humanos.

- Pinto, M. (1997). El principio pro homine. Criterios de hermenéutica y pautas para la regulación de los derechos humanos. En Centro de Estudios Legales y Sociales, CELS, La aplicación de los tratados de derechos humanos por los tribunales locales (pp. 163-172). Buenos Aires, Argentina: del Puerto. 
- Rodríguez Rescia, V. M. (1998). El Debido Proceso Legal y la Convención Americana Sobre Derechos Humanos. En H. Fix-Zamudio, LiberAmicorum, Volúmen II (pp. 1295-1328). San José de Costa Rica: Corte Interamericana de Derechos Humanos y Unión Europea.

- Saavedra Alessfandri, P. (2004, mayo). La Corte Interamericana de Derechos Humanos. Las reparaciones ordenadas y el acatamiento de los Estados. Ponencia presentada por el Secretario de la CrIDH en el Seminario sobre Instrumentos de Protección Regional e Internacional de Derechos Humanos en México, D.F.

- Saffon, M. P. \& Uprimny, R. (2007). Las masacres de Ituango contra Colombia: Una sentencia de desarrollo incremental. Revista Cejil: Debates Sobre Derechos Humanos y el Sistema Interamericano, Año II, 3, pp. 46-57.

- Uprimny, R. (2009). Reparaciones en Colombia: análisis y propuestas. Estudios en teoría del derecho, teoría política y derecho constitucional. Bogotá: Universidad Nacional de Colombia, Facultad de Derecho, Ciencias Políticas y Sociales.

- Zagrebelsky, G. (2005). Capítulo El derecho por principios. En Zagrebelsky, G. El derecho dúctil. Ley, derechos, justicia (pp. 109-122). Madrid: Editorial Trotta.

- Zagrebelsky, G. (2005). Capítulo El derecho por principios. En Zagrebelsky, G. El derecho dúctil. Ley, derechos, justicia (pp. 109-122). Madrid: Editorial Trotta.

\section{PÁGINAS WEB}

- Cebada Romero, A. (2002). Los conceptos de obligación erga omnes, iuscogens y violación grave a la luz del nuevo proyecto de la CDI sobre responsabilidad de los Estados por hechos ilícitos. Revista electrónica de Estudios Internacionales. (4), 1-14. Disponible en: http://www.reei.org/reei4/Cebada.PDF. Consultado el 18 de septiembre de 2009.

- Feria Tinta, M. (2008). La responsabilidad internacional del Estado en el sistema interamericano de protección de derechos humanos a veinticinco años del funcionamiento de la Corte Interamericana de Derechos Humanos: las lecciones del caso Hermanos Gómez Paquiyauri. En Instituto de Investigaciones jurídicas UNAM, La Corte Interamericana de Derechos Humanos a 25 años de su funcionamiento (pp. 63-113). Disponible en: http://www.bibliojuridica.org/libros/5/2496/8.pdf. Consultado el 16 de enero de 2010.

- Mijangos y González, J. (2007). La doctrina de la drittwirkung der grundrechte en la jurisprudencia de la Corte Interamericana de Derechos Humanos. Revista Teoría y Realidad Constitucional (20), 583-608. Disponible en: http://e-pacio.uned.es/fez/eserv.php? pid= bibliuned:TeoriayRealidadConstitucional2007$17 \& d s \mid D=$ docrina_drittwirkung.pdf. Consultado el 23 de octubre de 2009.

- Pérez Giralda, A. (2002). El proyecto de la Comisión de Derecho Internacional sobre responsabilidad de los Estados. Al final del camino. Revista electrónica de Estudios Internacionales. (4), 1-23. Disponible en: http://www.reei.org/reei4/Cebada.PDF. Consultado el 18 de septiembre de 2009. 